\title{
Service Output of Bank Holding Companies in the 1990s and the Role of Risk
}

\author{
J. Christina Wang ${ }^{* *}$ \\ Research Department \\ Federal Reserve Bank of Boston
}

September 2003

\begin{abstract}
:
This paper constructs a new measure of output for Bank Holding Companies (BHCs) over the period 1986 to 1999. This flow measure of bank value added follows from a unified model of bank operation that integrates theories of production, financial intermediation, and asset pricing. The primary contribution of the model is to demonstrate how one should account for risk when measuring the value added of bank services. One key implication is that the risk-related return on the funds banks borrow and lend should be excluded from the nominal value of the services banks produce, since the model recognizes that these funds are simply a particular kind of intermediate input. The new output measure is thus conceptually different from the existing ones even in terms of the nominal value. This paper focuses on deriving the nominal value of bank services according to the new measure, since no adequate data are available for compiling more accurate price indices for the services. Comparisons show that the new measure differs noticeably from the two existing ones. First, it is about $25 \%$ smaller than the measure stipulated in System of National Accounts 1993, and it is two orders of magnitude smaller than the measure used in virtually all the empirical studies of individual banking organizations. Second, the new measure exhibits quite different time series properties - in particular, it is more cyclical. This new model-based measure of bank output carries significant implications for the measurement of banking output in the National Income Accounts, providing the theoretical basis for a new approach that is consistent with basic principles. This paper can be regarded as a first attempt to resolve the host of data limitations on the implementation of the new measure. Better data and more accurate price indices for bank services will be needed before the new measure can become practical for National Income Accounting.
\end{abstract}

Keywords: bank holding company, service output, risk premium, value added JEL Classification: G21, D24, O47

I am grateful to Jim Adams and Matthew Shapiro for excellent advice and generous support, and to Gary Solon, Bob Barsky, Susanto Basu, and Lutz Kilian for valuable comments and advice. All errors remain my sole responsibility, and the views expressed here do not necessarily represent those of the Federal Reserve System.

* This paper, which may be revised, is available on the web site of the Federal Reserve Bank of

Boston at http://www.bos.frb.org/economic/wp/index.htm.

**E-mail: christina.wang@bos.frb.org 


\section{Introduction}

One longstanding issue afflicting an extensive empirical literature studying individual commercial banks is that there is little consensus on how to measure bank output and how to distinguish output from input. ${ }^{1}$ Regardless of the specific variant of output measure employed, virtually all the micro studies of bank production use the book value of various categories of financial assets and liabilities to measure bank output. On the other hand, System of National Account 1993 (SNA93) stipulates another measure for banking output in National Income Accounts. It considers the entire net interest income, which includes the return attributed to the risk premium of loans, banks' implicit compensation for providing services. But a new model of bank operation developed in Wang (2003a) shows that there are conceptual problems in both of these existing measures of bank output. Combining theories of production, financial intermediation, and asset pricing, the model shows that banks' value added comprises only their output of services and should not contain the risk-related return. It also clarifies the qualitative distinction between bank value added and the special intermediate input that banks use - the funds they borrow and lend. The model implies a new measure of bank value added that is, even in terms of the nominal value, clearly different from the SNA93 output measure, as well as from the other existing measure: it uses a flow variable-consisting of not only explicit fees but also the implicit revenue of bank services - as opposed to the stock value of financial instruments.

The purpose of this paper is to implement empirically the new model-based output measure and explore how and why its properties differ from those of the existing measures of bank output. The focus is on imputing the nominal value of bank service output, given that it represents the primary difference between the new measure and the existing ones. Furthermore, better data than currently available are needed to compile more accurate price indices for bank services. One major task here is to devise practical means to lessen the constraint of serious data limitations (e.g., unobserved bank-specific credit risk and price deflators for service output) on the imputation of the implicit revenue of bank services.

The new output series is constructed using Bank Holding Company (BHC) data, and it is found to differ noticeably from the existing measures in both its average magnitude and its fluctuations over a business cycle. These differences have important implications for the measurement of banking output in the National Income Accounts. This study should be viewed as a first attempt to map the theory to actual data and to tackle the difficulties posed by lack of data. Further efforts, especially in collecting more detailed and relevant data to construct better price indices for bank services, will be needed in the future to make the new measure practical for National Income Accounting. At the same time, the considerable difference between the new output series and earlier series implies that previous findings in the vast

\footnotetext{
${ }^{1}$ In this paper, unless otherwise specified, "banks" refers to commercial banks, which include independent banks, and (one-bank as well as multi-bank) bank holding companies. "Banking" refers to commercial banking.
} 
literature studying bank efficiency and the impact of bank mergers and other changes of industry structure should be re-examined using the new output series calculated here.

The new output series is computed for BHCs in order to reflect the overall production within a banking organization, since I expect important decisions concerning operations and risk to be made by holding companies rather than banks, although banks have been the unit of analysis in most previous studies. Moreover, the new measure should demonstrate its advantage over existing measures to the greatest extent in studying BHCs. This is so because the new measure can account for different risks among diverse classes of financial assets when calculating bank service output-a capability that is particularly necessary for analyzing BHC data. Relative to banks, BHCs have more complex portfolios as they typically comprise multiple banks engaging in diverse activities. The existing output measures, however, either ignore the issue of risk premia or rely on the restrictive assumption of homogeneous risk in each category of financial assets on the balance sheet. The new measure therefore should especially enhance the accuracy of output measurement for BHCs.

The paper is structured as follows. Section II summarizes the banking model underlying the new measure of bank output and then describes in general how to implement the implied new output measure. Section III constructs the new output series for BHCs, examines its properties, and compares it with the existing output measures. The section considers carefully the best proxies to overcome data limitations and discusses the likely bias in the resulting measurement errors. Section IV summarizes the findings.

\section{Bank Value Added, the Intermediate Input of Loanable Funds, and Risk}

\subsection{The New Model of Bank Operation}

Wang (2003a) has developed a unified model of bank operation. By integrating theories of production, financial intermediation, and asset pricing, it shows that the return banks earn on the funds lent is compensation for bearing the risk of borrowers' cash flows and thus should not be considered bank value added. Portfolio risk and bank service output are related in that they both affect the market value of a bank: risk determines the discount rate used to value future profits, while bank services generate part of the profits. But the quantity of service output is affected by risk only to the extent that portfolios of different risk require different amount of processing to resolve asymmetric information problems.

The model also clarifies the qualitative distinction between the value added banks create and the funds they lend, recognizing that the funds are merely an intermediate input in the production of banking services. Funds are analogous to goods bought and sold by retailers except for one critical difference: a good sold by a retailer has identical properties to the good bought by the retailer, whereas risk-the sole attribute - of funds borrowed (e.g., in the form of deposits) typically differs from the risk of the funds lent (i.e., loans). The resulting risk premia banks earn on funds are but a transfer from borrowers to ultimate 
suppliers of the funds and should not be counted as bank value added. Accordingly, the model classifies conventional banking into three qualitatively distinct functions: (1) mitigating the asymmetric information problems associated with uncertain investment returns, (2) financing loans with borrowed funds, and (3) providing transaction services. Both (1) and (3) consume real resources such as labor and physical capital and create the value added of a bank. In contrast, function (2) merely transfers the property and the income generated - "pure interest"- between ultimate users and suppliers of funds, and it creates no value beyond the return that depositors and bank shareholders with given preferences would demand for bearing certain risk. The model in turn partitions the gross interest income of a bank into pure interest and implicit revenues of bank services. According to asset pricing theories, pure interest depends on borrowers' risk. The interest is not bank value added, but it should still be considered part of (nominal) gross output. The residual interest income net of risk-related returns, plus explicit fees, then equals nominal bank value added. It is shown that this imputation of value added remains valid even when banks cannot fully resolve borrowers' private information or when banks have market power in supplying the services.

\subsection{The Implied New Measure of Bank Output}

I now discuss how to construct the new measure of bank value added as implied by the model in Wang (2003a), focusing on how to derive the value of the part of bank service output that is implicitly charged for. I divide a bank into three hypothetical divisions A, B, and C that perform the functions 1, 2, and 3 above, respectively, and I explain in detail how to map the theory to data in measuring the implicit output for each division. ${ }^{2}$ By definition, total revenue is the nominal value of output. The difficulty with banks is that their services are often not explicitly charged for. So the first task here is to identify the nominal value added when bank service revenues are bundled with pure interest and recorded as "interest income." Diagram 1 (reproduction of Figure 3 in Wang, 2003a) best summarizes the theoretical basis for the imputation. It depicts how to partition a bank's total interest receipt into separate revenue streams corresponding to the two kinds of value added (by Divisions A and C, respectively), providing the framework for all the following computations.

First, a bank's implicit nominal output of lending services by Division A equals its loan interest receipt net of risk-adjusted returns on the funds lent to borrowers: $\left[i^{B}-\mathrm{E}\left(r^{B}\right)\right] B \equiv \Delta i^{B} B$, where $i^{B}$ is the realized gross interest rate on a loan portfolio, $\mathrm{E}\left(r^{B}\right)$ is the expected rate of return corresponding to its systematic risk, and $B$ is the loan balance. It equals area I in Diagram1. To obtain $\mathrm{E}\left(r^{B}\right)$, one can apply an asset pricing model (e.g., the APT of Ross, 1976), regressing the portfolio's total return on the priced

\footnotetext{
${ }^{2}$ Since Division C's role is to serve depositors, I consider only transaction-type deposits, which contain a considerable component of services, in all the ensuing analysis of $\mathrm{C}$.
} 
factors. The fitted value is then taken to be $\mathrm{E}\left(r^{B}\right)$. Without adequate data to estimate $\mathrm{E}\left(r^{B}\right)$, returns on comparable market securities can serve as proxies for $\mathrm{E}\left(r^{B}\right)$. In turn, total nominal output equals the implicit output plus explicit fees, and, divided by a proper price deflator $\left(\mathbf{P}^{\mathrm{A}}\right)$, it yields the real output $\left(\mathbf{Y}^{\mathrm{A}}\right)$. Wang (2003a) portrays Division A as providing services of credit screening and monitoring, so the natural unit of $\mathbf{Y}^{\mathrm{A}}$ can be expressed as a vector of the numbers of specific types of loans originated and monitored. ${ }^{3} \mathbf{P}^{\mathrm{A}}$ should then be a vector of price indices constructed for such loan processings, and it may be bank-specific if there is imperfect competition in the market for lending services.

According to the model, the implicit nominal value of Division C's services is depositors' foregone interest income, i.e., the gap between actual deposit interest payments and the interest depositors would receive if they were paid the market rate for their funds: $\Sigma_{m}\left(r^{F}-r^{m}\right) D^{m} \equiv \Sigma_{m} \Delta r^{m} D^{m}$, where $r^{F}$ is the market rate (i.e., the risk-free rate, since there is deposit insurance), $r^{m}$ is the interest rate paid on type $m$ deposits, and $D^{m}$ is the total account balance of type $m$ deposits. It equals area IV in Diagram 1. Then, $\mathrm{C}^{\prime}$ 's real output $\left(\mathbf{Y}^{\mathrm{C}}\right)$ is calculated similarly to $\mathbf{Y}^{\mathrm{A}}$, and the challenge lies in constructing the right price deflator $\left(\mathbf{P}^{\mathrm{C}}\right)$. In theory, $\mathbf{Y}^{\mathrm{C}}$ is most intuitively expressed as a vector of the numbers of different types of transactions (e.g., check cashing and account opening). Constrained by limited data, the alternative is to use the number of deposit accounts of different types, assuming each account of a given type requires the same services every period. ${ }^{4} \mathbf{P}^{\mathrm{C}}$ should be constructed accordingly, and it is likely to be bank-specific, given the local and differentiated nature of deposit services. ${ }^{5}$

The "output" of Division B $\left(\mathbf{Y}^{\mathrm{B}}\right)$ should be the service flow of loanable funds over a certain period. This means the unit of $\mathbf{Y}^{\mathrm{B}}$ has two dimensions: currency unit and time interval (e.g., as expressed in dollars/year). Hence, the same amount of funds lent over different periods should be considered different $\mathbf{Y}^{\mathrm{B}}$. Given a time interval, one intuitive indicator of $\mathbf{Y}^{\mathrm{B}}$ is the real currency balance- the baseperiod constant value - of each category of loans, assuming they share the same systematic risk and their volume remains constant over each period. In essence, a stock variable is used as a proxy for the flow variable $\left(\mathbf{Y}^{\mathrm{B}}\right)$. There are two ways to calculate the real loan balance. One approach - the most commonly used - is to divide the book value of each category of loans by a broad price index, such as the GDP deflator. The other approach, analogous to deriving $\mathbf{Y}^{\mathrm{A}}$ and $\mathbf{Y}^{\mathrm{C}}$, divides B's interest income - its nominal output-by $\mathrm{E}\left(r^{B}\right) P_{t}$, where $P_{t}$ is the broad price index, and $\mathrm{E}\left(r^{B}\right)$ is equivalent to the rental price of a current dollar.

\footnotetext{
${ }^{3}$ In fact, this interpretation attempts to approximate the true natural content of $\mathbf{Y}^{\mathrm{A}}$-information - which is intangible and thus hard to measure. So, when one measures $\mathbf{Y}^{\mathrm{A}}$ using the number of loan originations, the loans in principle must all require the same quantity and quality of information processing.

${ }^{4}$ Existing studies use the dollar balance of deposits to measure the output of depositor services, implicitly assuming that the service flow is in proportion to the account balance. But Wang (2003a) has shown that the relationship between the quantity of services and the account balance is likely to be highly non-linear and time-varying.

${ }^{5}$ For example, consumers often choose nearby banks or banks with convenient branch and ATM networks.
} 


\subsection{Comparison with the Two Existing Measures}

There are two existing measures of bank output. The first one is used in the National Income Accounts (according to the 1993 System of National Accounts), and henceforth referred to as the SNA93 output measure. In contrast to the new measure, it ignores risk and considers the entire gap between bank interest receipts and interest payments as the nominal value of bank service output that is priced implicitly. Total nominal output then equals the sum of nominal implicit output and explicit fees. The latest revision (Moulton and Seskin, 2003) to National Income and Product Accounts (NIPA) applies the user cost approach pioneered by Hancock (1985) and proposes using the risk-free rate as the reference rate to partition net interest income into two parts: (1) the gap between a bank's actual interest receipts and the interest it would receive at the risk-free rate measures the nominal value of implicit services to borrowers (i.e., areas I to III in Diagram 1), and (2) the remainder (i.e., area IV in Diagram 1) equals the value of implicit services to depositors. So, given deposit insurance, the difference between the revised SNA93 measure and the new measure lies solely in the value of lending services.

Without maturity mismatch, the SNA93 measure of lending services should exceed the new measure by the risk premium accrued to the funds. Since services to business borrowers are an intermediate input into their production, the SNA93 measure thus lowers nominal GDP by the risk premium on business loans. On the other hand, it overstates lending services to consumers, which are counted as Personal Consumption Expenditures in GDP, by the amount of the risk premium on consumer loans. So, the net bias is unclear, depending on the relative magnitude of the two biases. The relationship between the two measures is reversed when the net return on funds turns negative. This occurs when the yield curve is inverted so that the rate of return on predominantly short-term liabilities exceeds that on long-term assets (mostly real estate loans). Relative to the new output measure, the SNA93 measure now understates and may even yield negative lending services to both firms and consumers, while the net bias in GDP is again unclear. Negative lending services pose a conceptual problem for the SNA93 output measure.

The other existing measure (henceforth referred to as the BV-based output measure) uses book values (BVs) of financial instruments on bank balance sheets as output, as mentioned above. It is applied in virtually all micro-level banking studies, with Rogers (1998) and Stiroh (1999) as the only exceptions. ${ }^{6}$ Rogers (1998) uses revenue directly as a measure of quantity for one type of bank output —off-balancesheet activities. However, he mentions the rationale for using revenue to measure the OBS output only in passing, and he provides no explanation for combining OBS revenue with the BV-based measure of the output of loans and securities. Stiroh (1999) applies Rogers' approach in one of the specifications of his

\footnotetext{
${ }^{6}$ Berger and Humphrey (1997) survey the literature of bank efficiency studies, reviewing a variety of efficiency definitions and estimation techniques.
} 
efficiency analysis. All of the other studies apply one of the three specific types of BV-based measures: the asset, the user cost, or the value-added approach. They differ merely in whether deposits are considered an output, and thus they generate similar results (see Berger and Humphrey, 1997). So, I examine only the asset approach in this paper, because it treats only the financial assets as bank intermediation output, leading to a measure of output most similar to that used for Division B's gross output of loanable funds.

\section{Data and Empirical Results}

\subsection{The Data and Sample Selection}

All the BHC balance sheet and income statement data (on a consolidated basis but excluding nonbank subsidiaries) come from the quarterly Reports of Condition and Income (form FR Y-9C) filed by all the FDIC-insured BHCs. The Federal Reserve Bank of Chicago maintains these data, along with data of all the BHC mergers since 1986. The sample runs from the second quarter of 1986 to the second quarter of 1999. All the balance sheet data are end-of-quarter figures. All the interest rates are monthly secondary-market rates from the Federal Reserve Economic Database (FRED) at the Federal Reserve Bank of St. Louis.

In the sample panel, each combined BHC formed after a merger is considered a new entity, although it retains the acquirer's identification number. The first quarter after each merger is removed to avoid potential data anomalies incident to business combinations. Since all the flow variables reported in the income statement are year-to-date values, the first observation of a BHC's time series starting from the second quarter or later also has to be removed, as the quarterly values cannot be derived for such quarters. For multi-tier BHCs, only the top-tier BHC is included in the sample. Observations with implausible values for some revenue or cost variables (e.g., negative expenses on fixed assets or employee salaries) are also removed. ${ }^{7}$ To prevent BHCs with heavy non-bank operations from skewing the results, I exclude the BHCs whose non-bank assets exceed $10 \%$ of the consolidated total assets. Last, a BHC must have at least twelve quarters of time series data to be included in the final sample. ${ }^{8}$ Overall, the selection criteria trim the initial data set of 77,961 observations belonging to 4527 BHCs down to a final sample of 36,616 observations belonging to 1505 BHCs. It is an unbalanced panel with BHC time

\footnotetext{
${ }^{7}$ The only patterns in the occurrence of such negative values seem to be that they appear most often in the fourth quarter and concentrate around the first year a banking organization is formed.

${ }^{8}$ This restriction is imposed to obtain a final sample identical to the one used for estimating the production and cost functions in Wang (2003b). 45,580 observations from $3181 \mathrm{BHCs}$ remain before it is imposed, and they are called the usable observations. This requirement decreases the sample mean total assets (by $41 \%$, see Table 2 and Figure 8) and the cross-section variance of the variables, since most of the entities excluded are large BHCs, which merged often and thus have short time series between mergers. But the relative magnitudes and other relationships between the new output measure and the two existing measures remain about the same.
} 
series of up to 44 quarters. Some BHCs have missing observations in the middle of the time series, but their occurrence exhibits no regularity and is thus assumed to be random. See Table 2 and Figure 8 for comparisons of the average total asset size of a BHC for different size groups and years, respectively, across the original sample, all usable observations, and the final sample.

The most prominent yearly pattern of the three major loan categories is the steady relative increase of real estate (RE) loans in the 1990s, crowding out C\&I and consumer loans. (See Figures 7, B.1 and B.2 for summary statistics of total BHC assets and the relative magnitude of major balance sheet and income statement categories by year and by asset size.) One explanation is that the capital adequacy requirement assigns a relatively low risk weight to residential mortgages, making RE loans more attractive to banks. Across size groups, large banks tend to have relatively more loans (especially C\&I and consumer loans) but less deposits. Over time, deposit liabilities fall relative to subordinated debt across the board. See Appendix B for a more detailed discussion of the other patterns of the assets, liabilities, and incomes of the sample BHCs, and possible explanations.

\subsection{Imputation of the New Measure of Bank Output}

This section concentrates on imputing the part of bank service output that is implicitly charged for, according to the new measure. This task is made difficult mainly by limitations on data availability. So this section discusses in detail how to form proxies that most closely match the definition in the model, as well as the potential bias in the resulting measurement errors. It also pays special attention to the conceptual issues that arise because of the implicit pricing of those bank services. At the same time, the issue of foremost importance in imputing the output of Divisions $\mathrm{A}$ and $\mathrm{C}$ is that their value added must be net of the materials inputs (e.g., stationery and utilities) used in providing services to borrowers and depositors. This paper is the first to clarify this issue, and Appendix A discusses the exact calculations, given the available data. Table 1 summarizes the imputation of A's and C's output, and Appendix C lists the data items used.

To impute A's implicit output, interest rates on comparable market securities are used as proxies for $\mathrm{E}\left(r^{B}\right)$ —expected rates of returns on loan portfolios, since reported data do not allow direct estimation. ${ }^{9}$ The quarterly rate of 90-day commercial paper (CP) approximates expected rates for C\&I, agricultural, and consumer loans and for lease financing receivables. ${ }^{10}$ For loans to finance dealings in securities, I use

\footnotetext{
${ }^{9}$ Using the same market rate for all banks underestimates the $\mathrm{E}\left(r^{B}\right)$ s for banks with loans subject to higher systematic risk, and thus biases up their $\mathbf{Y}^{\mathrm{A}} \mathrm{s}$. But this enables me to focus on studying the properties of the new output measure, and the bias should be minor as fixed-income securities likely have similar systematic risk.

${ }^{10}$ The CP rate seems a valid choice for C\&I and agricultural loans, which mostly finance working capital. Even though consumer loans may be more risky and lease financings have longer maturities than represented in the CP rate, it should not affect the estimation results materially, since both loan categories constitutes a small fraction of the entire portfolio. The results also remain similar if the 180-day CP and the prime loan rates are used instead.
} 
the federal funds rate, which is very close to the overnight repo rate that is typically used as the benchmark for lending to dealers and brokers. For real estate lending, I use the quarterly rate on the Federal Housing Administration (FHA) mortgage from the Federal Reserve Board. To the extent that RE loans have roughly the same systematic risk, the FHA rate should capture it. ${ }^{11}$ Note that deposit insurance does not bias the imputed nominal value of $\mathbf{Y}^{\mathrm{A}}$ under the new measure (see Diagram 1) but biases up the nominal value of the SNA93 measure of output for banks that take on more risk. The total value of A's lending services equals the sum of its implicit nominal output and explicit charges on borrowers (e.g., origination fees). To derive the real value of A's output, I experiment with two proxies: the price index for "services furnished without payment by financial intermediaries" published by the BEA, and the GDP deflator. The former grows faster than the latter during the sample period, but which index is used makes little difference in the parameter estimates. ${ }^{12}$

Two things are crucial for the correct imputation of A's implicit output. The first is that the loss of loan principal due to default must be subtracted from the reported interest receipts of each bank, otherwise the imputed value will overstate A's implicit output. ${ }^{13}$ This problem is relevant for the SNA93 output measure as well, and it is considered for the first time in this paper. I use the time series mean of loan charge-offs for a BHC (denoted by $\bar{d}$ ) to approximate the expected default rate $\left(d^{B}\right)$, which is equal to the loss of loan balances on average. ${ }^{14}$ The other issue is that the actual receipt of gross interest must be adjusted for the realized default rate before the partition of interest income based on the new banking model can be applied. The model maps to a partition of expected gross interest income, but only realized returns are observed. So I propose a crude method to correct for the random realization of default in each

${ }^{11}$ The portfolio return of fixed-rate real estate (RE) loans also depends on the maturity structure of the entire portfolio. That is, $\mathrm{E}\left(r_{t}^{P}\right)=\Sigma_{j} w_{j}\left(\mathrm{E}\left(r_{t-j}^{B}\right)\right), j \geq 0$, where $\mathrm{E}\left(r_{t}^{P}\right)$ is the period- $t$ expected return of a RE loan portfolio, $\mathrm{E}\left(r_{t-j}^{B}\right)$ is the expected return on loans issued $j$ periods before, and $w_{j}$ is their value weight. A crude proxy for $\mathrm{E}\left(r_{t}^{P}\right)$ without observing $w_{j}$ is to use $\mathrm{E}\left(r_{t}^{B}\right)$ instead (i.e., the FHA rate here), which may be unbiased, but can have high variances. But the FHA rate cannot account for premium differentials attributed to different maturities and guarantors within residential mortgages, or the higher risk premium of commercial mortgages.

12 The conceptually correct deflator for A's output does not yet exist. Appendix A discusses some of the problems.

${ }^{13}$ As shown in section 2.2, $\mathrm{E}\left(r^{B}\right)$ is to approximate the average realized return on loans, which should contain the losses of not only interests but also loan principal due to default. The loan interests reported on banks' income statement, however, does not include the losses of face value, because the accounting rule stipulates that such losses be charged against a contra asset account (viz., "allowance for loan losses") so that they do not directly reduce a bank's equity capital. So the reported interests data must be adjusted by removing the face-value losses.

${ }^{14}$ If $d^{B}$ varies over time, its ideal proxy should be the charge-offs in only those periods when the relevant loans are outstanding. But there are no data on the actual maturity of loans, and using $\bar{d}$ should not cause much bias for most sample BHCs, as they have short time series, although it may bias those few with long time series. By comparison, previous studies treat the "provisions for loan losses,"which is the non-cash cost item charged to replenish the "allowance," as part of the cost and use the loan BVs net of the allowance as the output measure. 
period $\left(d_{t}^{B}\right)$ : adjusting the estimate of $\mathrm{E}\left(r^{B}\right)$ by $\left(1-d_{t}^{B}\right) /(1-\bar{d})$, since the realized interest is $\left(1+R^{B}\right) Y^{B}$, equal to $\left[\left(1-d_{t}^{B}\right) /\left(1-d^{B}\right)\right]\left(1+\mathrm{E}\left(r^{B}\right)\right) Y^{B} \approx\left[\left(1-d_{t}^{B}\right) /(1-\bar{d})\right]\left(1+\mathrm{E}\left(r^{B}\right)\right) Y^{B} .{ }^{15}$

To impute the nominal value of Division C's implicit service output, I use the 90-day Treasury bill rate as depositors' expected rate of return on funds. Total deposits net of time deposits (with a balance greater than $\$ 100,000)$ approximates the unavailable balance of transaction accounts. ${ }^{16}$ The total value of C's transaction services equals the sum of its implicit nominal output and explicit charges on depositors (e.g., safe deposit box rentals and fees for money orders). To derive the real value of C's output, I use (as a proxy for the ideal $\mathbf{P}^{\mathrm{C}}$ ) the price index compiled by the BEA for personal consumption expenditures on "bank service charges, trust services, and safe deposit box rental." Finally, a bank's aggregate value added equals the sum of A's and C's value added.

The "output" of loanable funds is approximated using the real book values of all the interestearning financial assets, calculated as the nominal values divided by the GDP deflator. ${ }^{17}$ I categorize the fund output into four groups: (1) investment securities, (2) business lending, equal to C\&I loans plus lease financing receivables, (3) consumer loans, and (4) real estate loans.

Last, I compute the two existing measures of bank output. The BV-based output uses exactly the same quantity indicators - real book values of four earning assets — as the output of loanable funds. The nominal output according to the SNA93 measure equals net interest income plus explicit services fees. When the latest NIPA revision is applied, the nominal value of depositor services is identical to its counterpart in the new measure, whereas the value of lending services is greater than its counterpart-by an amount that represents the entire gap between the revised SNA93 and the new output measures. So, to understand the difference between these two measures in general, it is sufficient to compare the new measure with either the original or the revised SNA93 measure; I choose the former in the following comparisons. To compute the real output, I experiment with the same deflators as those used for the new output.

${ }^{15} \mathrm{E}\left(r^{B}\right)$ can be a reasonable proxy for the realized rate of return $\left(R^{B}\right)$ on funds under a special condition. If a bank's loan portfolio has low geographical or industry concentration so that most loans have uncorrelated default risk, then the average realization of default $\left(d_{t}^{B}\right)$ will equal the expectated $\left(d^{B}\right): d_{t}^{B} \approx d^{B}$. In turn, the realized return on the loan portfolio should, on average, also equal the expected, i.e., $R^{B}=\left[\left(1+\mathrm{E}\left(r^{B}\right)\right) /\left(1-d^{B}\right)\right]\left(1-d_{t}^{B}\right)-1 \approx \mathrm{E}\left(r^{B}\right)$.

${ }^{16}$ To the extent that this balance still contains accounts with more than $\$ 100,000$ (i.e., beyond the limit for FDIC insurance, so presumably requiring a higher rate of return), using the 90-day T-bill rate may understate C's nominal output somewhat.

${ }^{17}$ Off-balance-sheet (OBS) instruments, which redistribute risk without initial fund input (e.g., loan commitments and derivative contracts), are financial products qualitatively similar to Division B's output. Market values of the instruments can be used to measure their output. I do not yet consider them in the output of loanable funds in the current study, partly because conceptually it is still unclear how to aggregate them with the on-balance-sheet financial instruments. On the other hand, the fees generated by OBS activities (data item 4399) are included in A's output to recognize that OBS activities also generate real services while consuming real resources (e.g., labor). In principle, implicit OBS services can be similarly imputed according to the new banking model. 


\subsection{Comparison of the New Bank Output with the Existing Measures}

Next, I compare the properties of the new and the old output series. First, the three measures of output are highly correlated: the new output series correlates most closely with the SNA93 output ( $\rho=0.95)$, next with long-term lending ( $\rho=0.91$ for RE loans), and less with short-term (C\&I) loans $(\rho=0.74)$. Second, by construction, the new output should be smaller than the SNA93 output, and the data confirm that the former is on average $72 \%$ of the latter (see Figure 1). (Note that all the difference is in lending services.) Assuming all the RE loans are made to consumers, then the SNA93's overstatement of lending services to consumers exceeds that of services to firms (via C\&I loans). This has a significant implication for GDP: the SNA93 methodology for NIPA is likely biasing nominal GDP upward by overstating bank lending services on net. Conditional on the price deflators used, the SNA93 measure leads to an upward bias in real GDP as well. But more accurate deflators for each type of lending services are required to calculate precisely the net bias to real GDP.

In terms of the average (annual) growth in the period 1988 to 1998, the new output has the highest rate- $3.9 \%$ per year. ${ }^{18}$ Total bank earning assets (to proxy an aggregate measure of the BV-based output) grew $1.5 \%$ per year, and the SNA93 output series actually declined $2.5 \%$ each year. The widest gap occurred in the period 1993 to 1998, when the new output series grew at an annual rate of $7.8 \%$, whereas earning assets stagnated and the SNA93 output series declined 2.9\% per year. This implies that the two existing output measures may have understated the growth of the banking industry over the past decade.

Given the unbalanced panel, the annual growth rate of the industry output is the average of growth rates of all the BHCs that have data in a given year, and the rates according to the three measures are reported in Figure 2. Fluctuations in the new measure of bank output are mostly driven by the implicit component, since the explicitly priced service output is stable over time. It fell in the last recession (1990 to 1991), which coincided with the tightening of bank capital requirements following the Basel Accord, and the drop was mainly in depositor services by Division C (Figures 3-5). Similarly, among the components of the BV-based output, C\&I and consumer loans fell in 1990 to 1992, and RE loans slowed down, whereas securities holding rose. ${ }^{19}$

The Solow residual is computed for the new output, and its fluctuations mirror those in the output (Figure 5), since growth rates of the primary inputs $(L$ and $K$ ) are stable at $2 \%-4 \%$ over the period 1986

\footnotetext{
${ }^{18}$ The growth rate is calculated as difference in log levels. Growth rates in 1986, 1987, and 1999 cannot be properly calculated because of incomplete data. All the figures are computed using all usable observations.

${ }^{19}$ In fact, the sample average total bank assets increased then, while the fraction of loans declined. The cyclical composition of bank assets over business cycles is also documented in Bernanke and Blinder (1992). The fall in securities in 1994 is due to a change of variable definition in data reporting.
} 
to $1997 .^{20}$ The output-weighted sample mean of its annual growth rate is $2.4 \%$. I then examine how the ratio between explicit fees and implicit incomes changes over time. I find little evidence that banks are increasing the share of explicitly priced services, as the share barely changes across years and accounts for roughly only $30 \%$ of A's total output (Figure 3), and $20 \%$ of C's output (Figure 4 ). ${ }^{21}$

The sharp dip in C's output in 1990-91 may simply mean that the production of bank services is highly cyclical. But a more plausible explanation is based on depositor relationships: because of search costs, depositors tend to stay with a bank unless the return falls below a threshold; banks have to expend resources to sign up new depositors, but they can charge a higher markup on their services to existing customers and price discriminate (shown in Wang, 2003a). Hence, banks have an incentive to lower the price of their services during recessions, expecting to recoup the loss in future booms. If the price deflator cannot fully account for the cyclical markup, then the measure based on depositors' foregone interest income will overstate the true bank output in booms while understating it in recessions. In the case of A's output, two forces working in opposite directions may have partially offset each other and resulted in less fluctuation. On the one hand, bank loans may be relatively riskier during recessions so that using market rates as the expected rate of return may lead to an overstatement of the nominal output; on the other hand, banks may charge a lower markup on their information-processing services to avoid aggravating the moral hazard problem during bad times. The issue of markups on bank services is both interesting in its own right and important for developing better price indices. In future work, more accurate (and bank-specific) deflators may be calculated using more detailed data and appropriate models of competition in the relevant geographical (or product) markets.

One interesting finding is that nominal service output according to the new model equals total non-interest cost, implying zero economic profit on average, even though the new output measure is constructed independent of any cost information. This result may serve as informal evidence for the validity of the new output measure, since competition both between banks and from non-bank financial institutions intensified during the sample period, and free entry (without strategic actions) should lead to zero economic profit in the long run. But this finding becomes a sign of inefficiency in bank operationS to the extent that there exist regulatory subsidies and barriers to entry in banking and they are not fully captured by the rate-of-return proxies and price indices used in this study to impute bank output.

In conclusion, the new measure of output differs noticeably from both existing measures. Given the data, the new measure generates higher average industry growth than the other two and exhibits a

\footnotetext{
${ }^{20}$ Defined as $\left(d y-s_{K} d k-s_{L} d l\right)$, where $d y, d k$ and $d l$ are the respective growth rates of $Y, K$ and $L$, and $s_{K}$ and $s_{L}$ are the income shares of $K$ and $L$, respectively.

${ }^{21}$ An increasing share of explicit output will make it easier to compute bank output and also provide a reference for judging if the imputed output according to the new method is reasonable, in which case aggregate output should be relatively stable and increasingly comparable with actual fee income.
} 
different growth pattern. But it also shows higher variances, possibly in large part due to measurement errors in the new output series. In contrast, the BV-based measure is likely to understate the growth of bank output, while its magnitude is irrelevant for measuring bank value added. The SNA93 measure overstates the magnitude of bank output but may have understated its growth.

\section{Conclusions}

This paper constructs a new measure of bank output which is implied by a unified model of banking that takes into account the risk of the funds that banks borrow and lend. Over a 14-year period (1986 to 1999), comparisons show that this new output series for a group of BHCs differs noticeably from the two existing output measures - one based on book values of assets, and the other based on net interest income (SNA93).

Three findings of the new output measure are worth noting. First, the new measure is more than $25 \%$ smaller than the measure based on net interest income, and more importantly, it has different time series properties. It is more volatile over time, and it appears to be affected more by the recession in 1990 to 1991 than the other measures. This may mean that banking is cyclical, but it seems more plausible to hypothesize that banks have countercyclical markups on services so that the fluctuations in real output would appear smaller if more precise price deflators were available. So, one of the future tasks should be to construct better (and bank-specific) deflators, using more detailed data and appropriate models of market competition. Second, the new series shows a higher growth rate than the two existing measures, especially in the latter half of the sample period (1993 to 1998). This seems more consistent with the observation that investment grew steadily during those six years. Last, one interesting result is that the nominal value of the new output equals banks' non-interest cost on average, implying zero profit in the long run. This may be viewed as informal support for the new measure of bank output if one assumes that the free-entry condition holds in banking at least in the long run.

These findings have important implications for the measurement of banking output in National Income Accounts, in terms of both the average magnitude and the fluctuations over business cycles. The SNA93 methodology is likely biasing upward banking output in gross domestic product, as the overstatement of lending services to consumers exceeds that of services to firms. But more detailed data of the portfolio risk and service price deflators for individual banks are needed to construct a more accurate output series in the future. At the same time, the considerably different properties of the new output series imply that the results of previous studies of bank efficiency should be re-examined. In particular, I intend to explore to what extent the common findings of near constant returns to scale and a high degree of cross-bank efficiency dispersion are driven by the use of asset book values as output in 
estimating the cost functions of banking organizations. Moreover, the impacts of mergers and other industry changes should be re-analyzed using this new output series as well. 


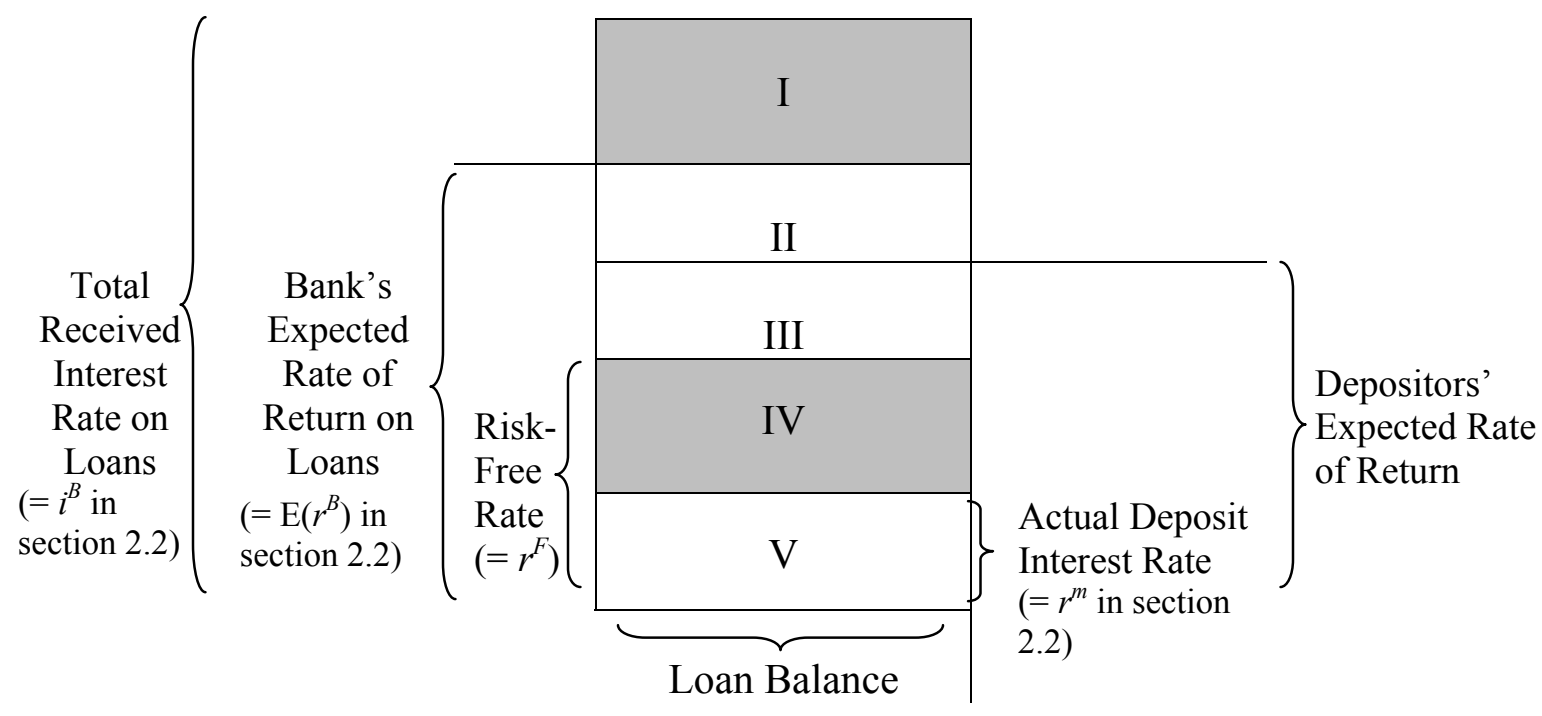

\section{Diagram 1. Decomposition of a Bank's Total Interest Receipt}

Notes:

1. The content of each area:

Area I: implicit fees for intermediation services in lending (e.g., origination and monitoring)

Area II: loan risk premium

Area III: deposit insurance premium

Area IV: implicit fees for transaction and payment services (e.g., mostly to depositors)

So,

Area V: deposit interest payment

Area $(\mathrm{I}+\ldots+\mathrm{V})$ : a bank's total receipt of loan interest income

Area $(\mathrm{II}+\ldots+\mathrm{V})$ : the bank's expected return on the funds given the loans' systematic risk

Area $(\mathrm{III}+\mathrm{IV}+\mathrm{V})$ : depositors' expected return on deposits given the risk of the bank's loan portfolio (if without deposit insurance)

Area $(\mathrm{IV}+\mathrm{V})$ : risk-free return $\times$ deposit balance

N. B.: when there is equity, the two deposit-related rates on the right of the block and the risk-free rate should be adjusted by (deposit balance/loan balance).

2. The risk-free rate is the rate of return required by depositors given deposit insurance, whereas the "depositors' opportunity cost of capital" is the return they would demand without deposit insurance. The two rates should be very close (or the same) for banks with very low credit risk (say, having AAA-rated bonds outstanding). 


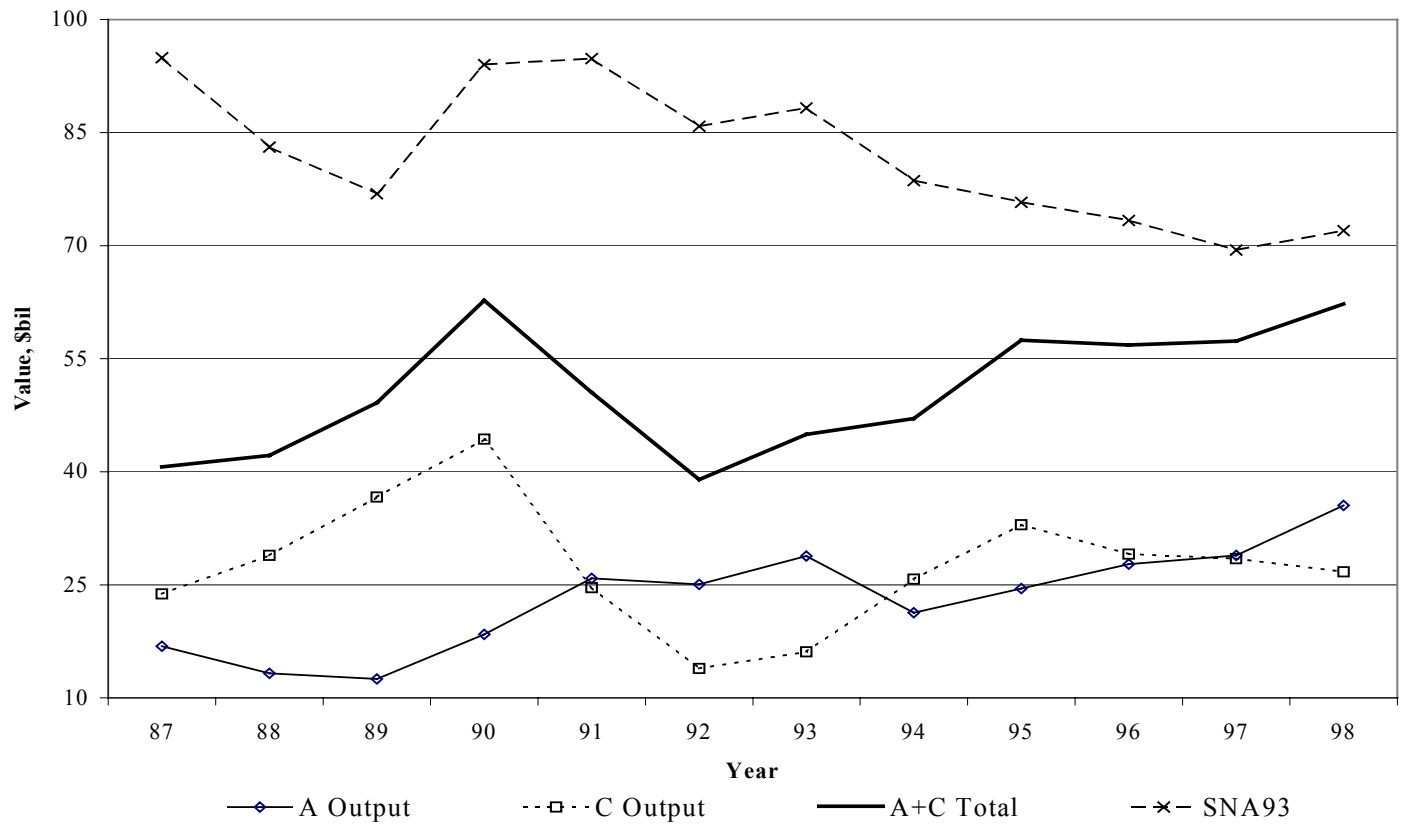

Figure 1. Levels of the New Measure of Aggregate Bank Value Added $(A+C)$, Its Component of Info-Services (A) and Depositor Services (C), and the SNA93 Measure of Output

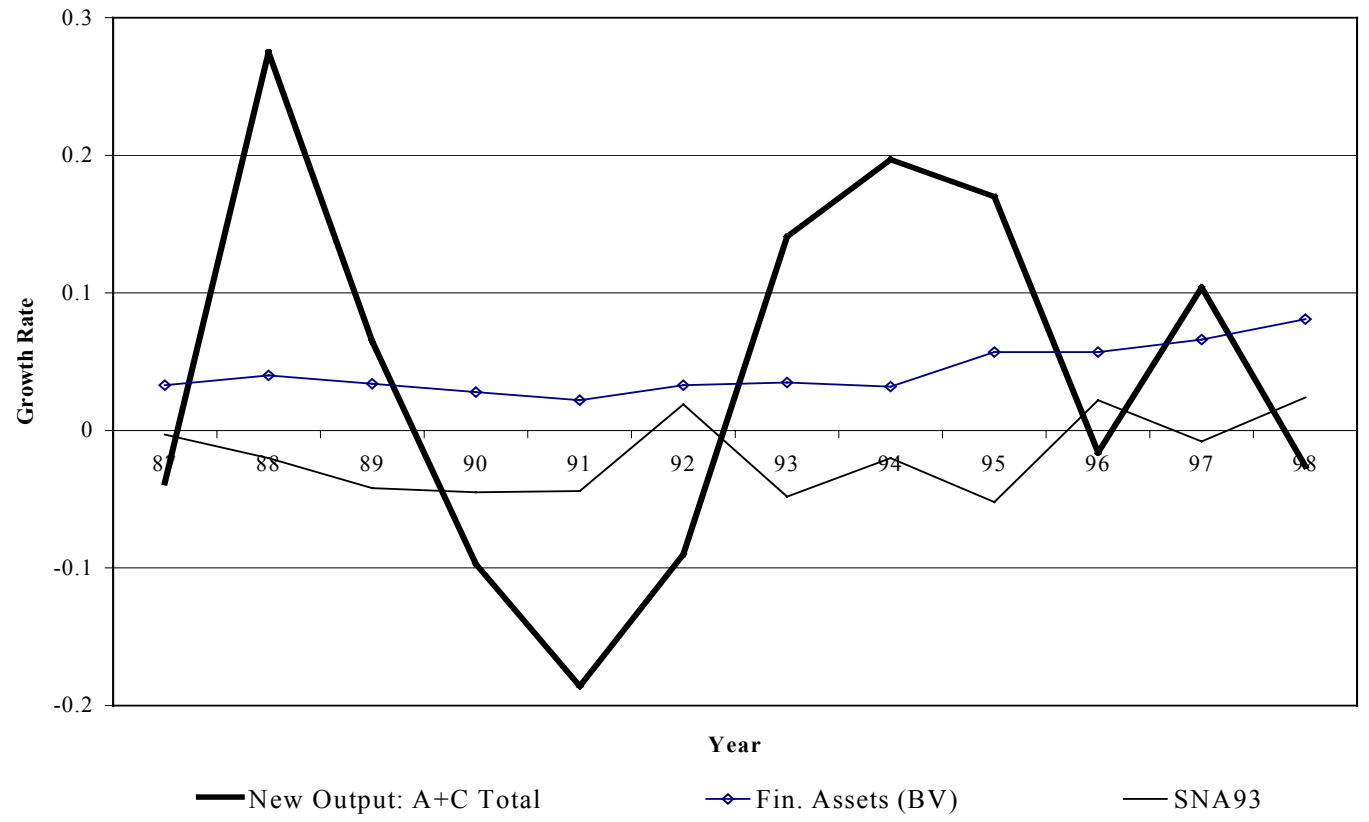

Figure 2. Annual Growth Rates of Bank Output According to the Three Measures 


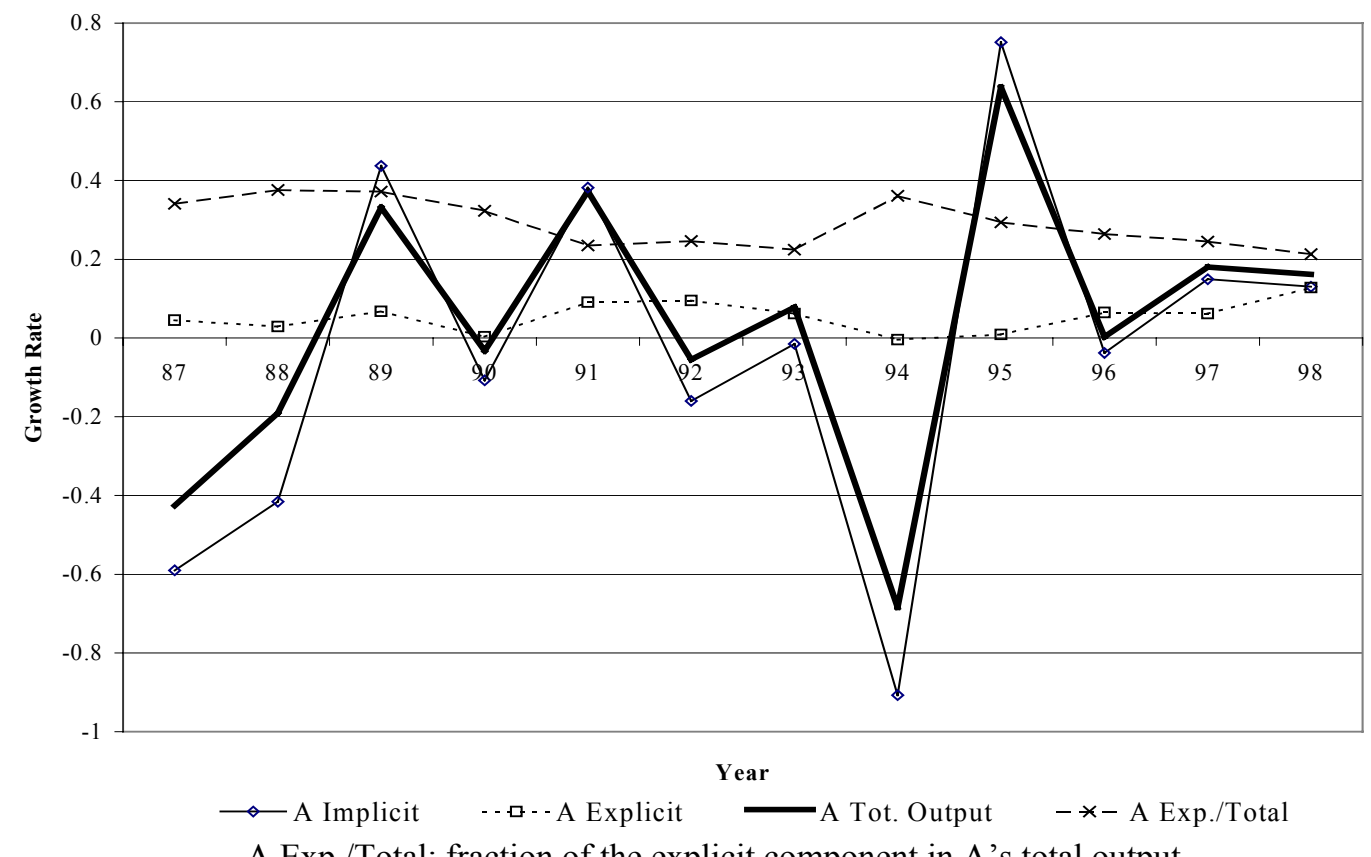

A Exp./Total: fraction of the explicit component in A's total output

Figure 3. Growth of Bank Value Added I (Division A's Output): Info-Processing Services

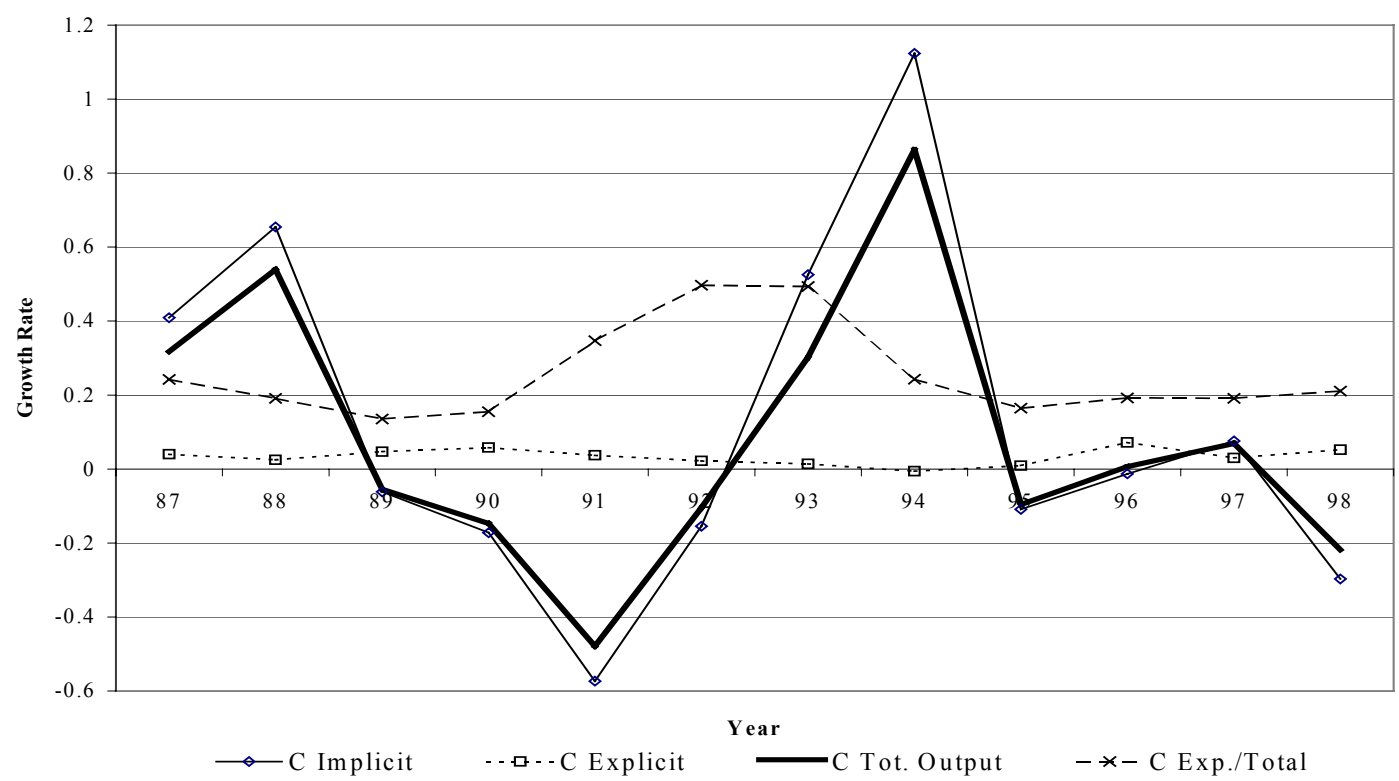

C Exp./Total: fraction of the explicit component in C's total output

Figure 4. Growth of Bank Value Added II (Division C's Output):

Depositor Services 


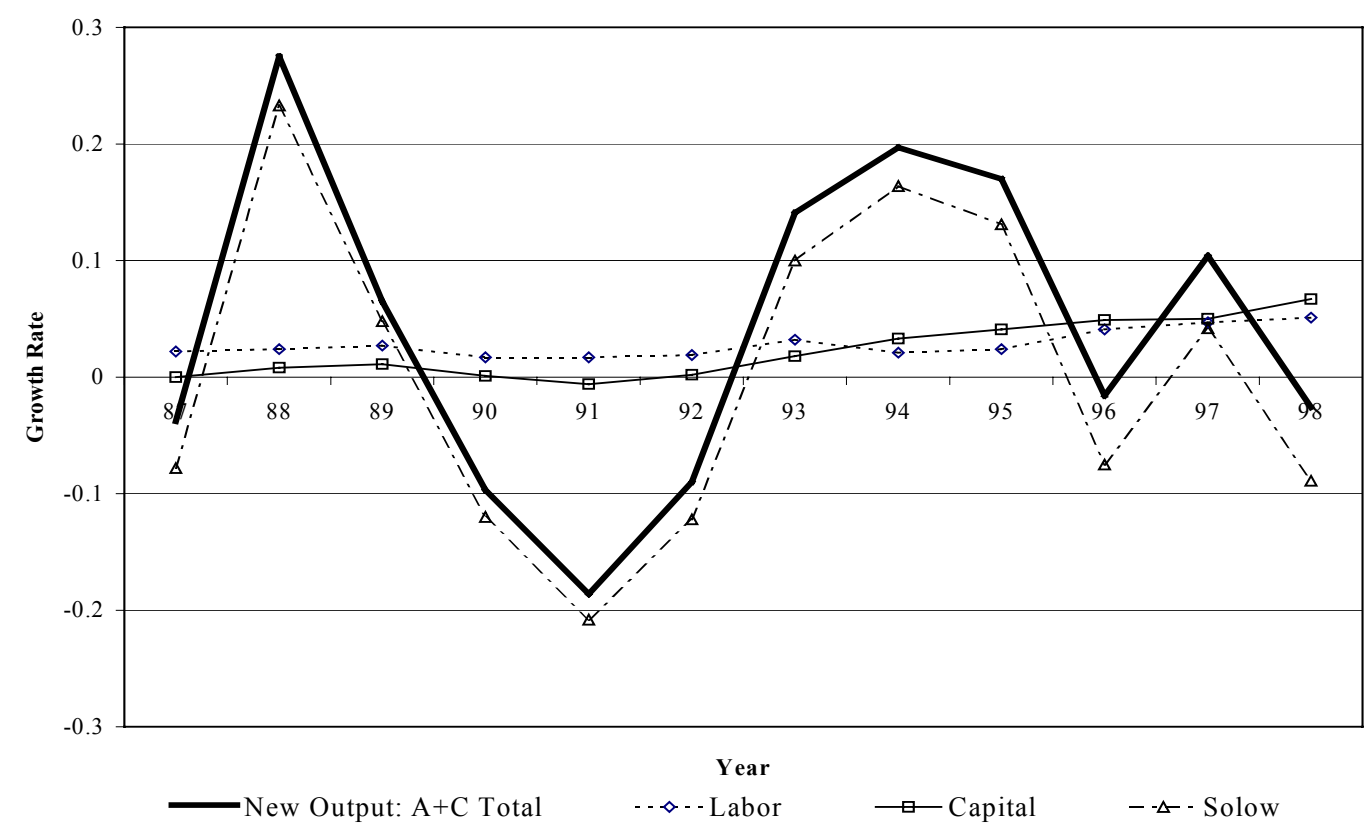

Figure 5. Annual Growth Rates of the New Measure of Bank Output, the Solow Residual, and Inputs of Labor and Capital

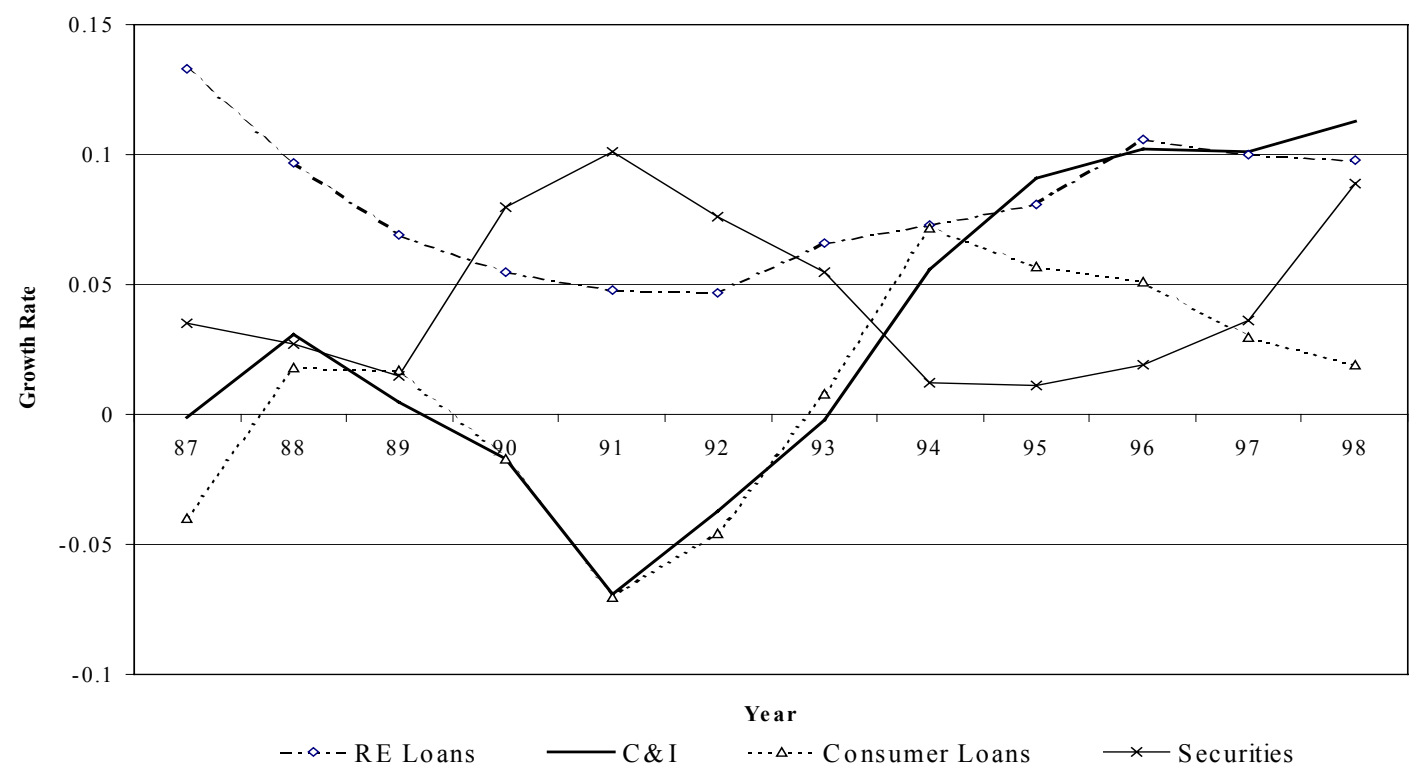

Figure 6. Growth Rate of the BV-based Measure of Bank Output (Book Value of Financial Assets) 


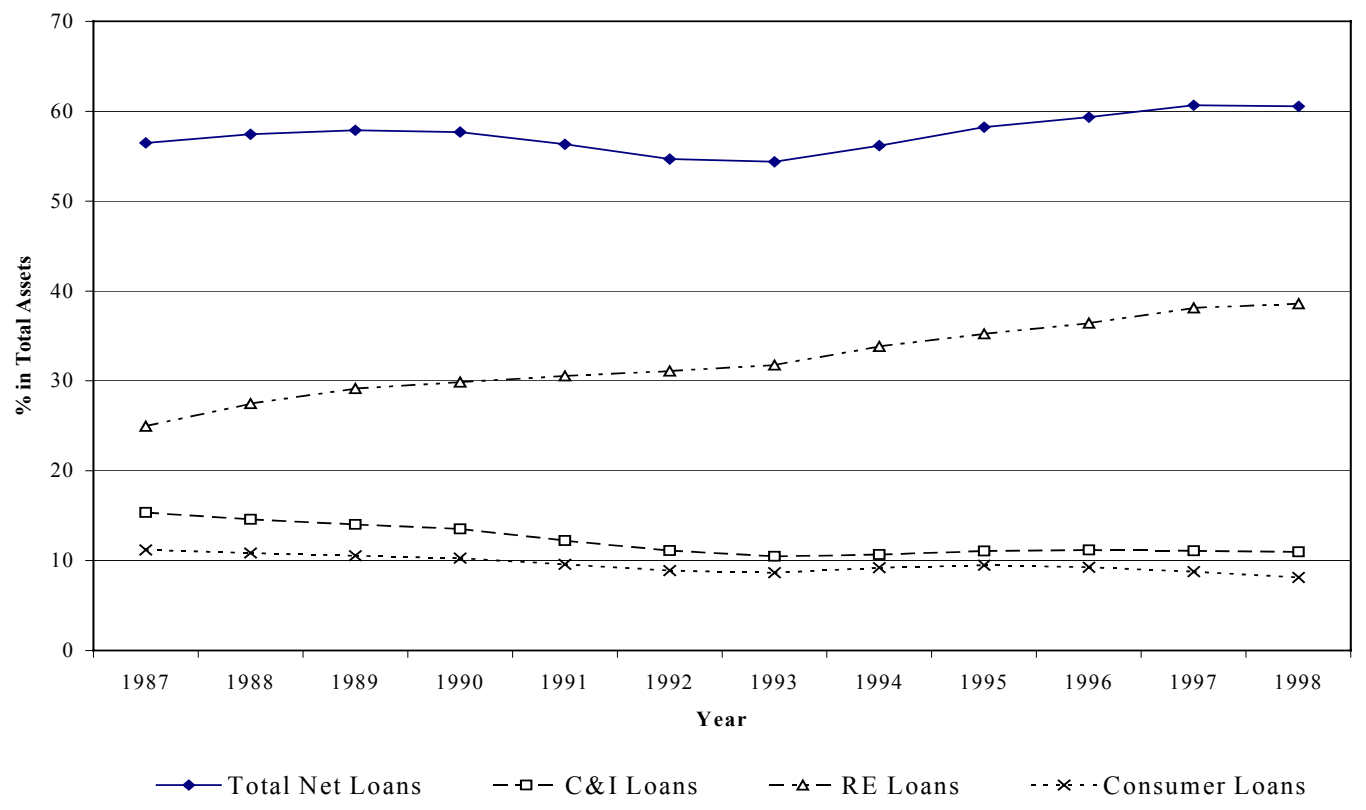

Figure 7. Yearly Pattern of the Composition of Loan Categories in Total Bank Assets

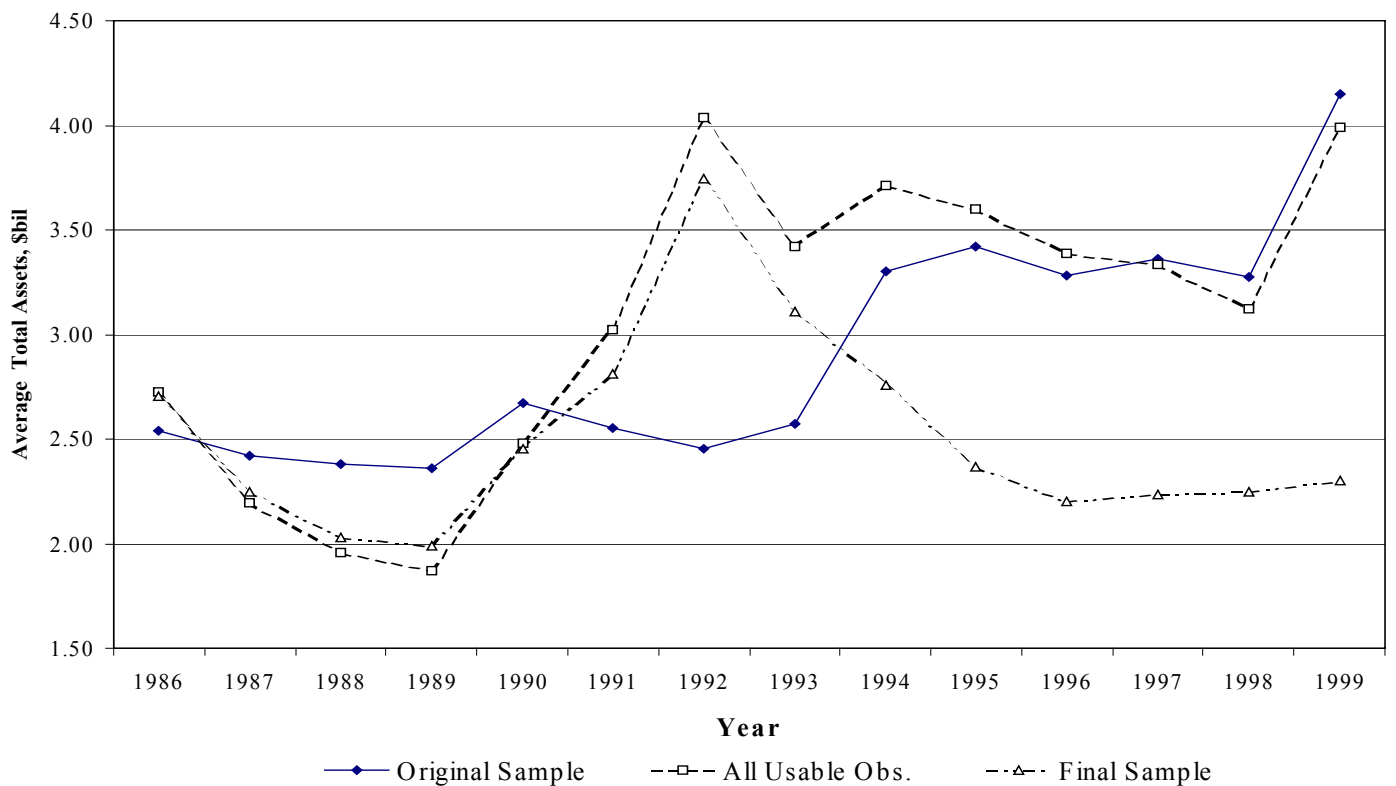

Final sample: BHCs with time series of usable observation $\geq 12$

Figure 8. Yearly Pattern of Sample Average Total Assets (Different Subsets of the Sample) 
Table 1. Output Measurement for Divisions A, B, and C of a Bank

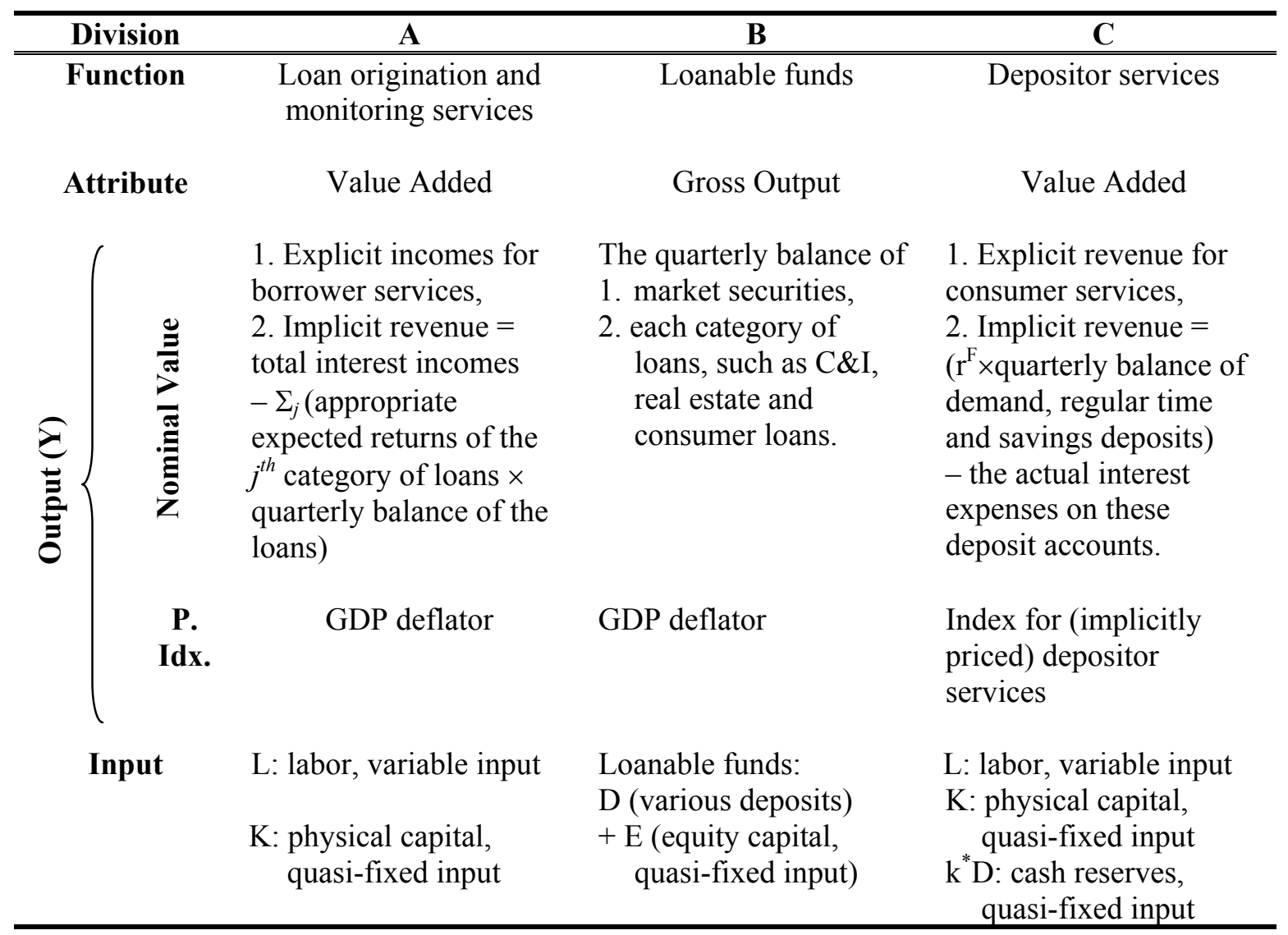

Notes:

1. For the output of Division B, I currently classify all the loans into three categories: (1) commercial loans, which include C\&I loans and lease financing receivables, (2) real estate loans, and (3) consumer loans.

2. $\mathrm{r}^{\mathrm{F}}$ : risk-free interest rate, and the 90-day Treasury bill rate is used.

3. The price index for Division C's output is compiled by BEA, and maintained in the I database. 
Table 2. BHC Average Total Assets of the Original Sample, All the Usable Observations, and the Final Sample

\begin{tabular}{cccc|ccc}
\hline \multirow{2}{*}{$\begin{array}{c}\text { Size Group } \\
(\$ \text { mil })\end{array}$} & \multicolumn{3}{c|}{ Assets (\$mil) } & \multicolumn{3}{c}{ Liabilities (\$mil) } \\
\cline { 2 - 7 } & $\begin{array}{c}\text { Original } \\
\text { Sample }\end{array}$ & $\begin{array}{c}\text { All Usable } \\
\text { Obs }\end{array}$ & $\begin{array}{c}\text { Final } \\
\text { Sample }\end{array}$ & $\begin{array}{c}\text { Original } \\
\text { Sample }\end{array}$ & $\begin{array}{c}\text { All Usable } \\
\text { Obs }\end{array}$ & $\begin{array}{c}\text { Final } \\
\text { Sample }\end{array}$ \\
\hline$<500$ & 224.4 & 226.4 & 243.7 & 205.9 & 208 & 223.7 \\
$(500,1,000)$ & 746 & 739 & 734.2 & 683.1 & 676.8 & 672.9 \\
$(1,000,5,000)$ & 2455 & 2453 & 2324 & 2256 & 2255 & 2146 \\
$(5,000,10,000)$ & 7324 & 7395 & 7700 & 6749 & 6827 & 7128 \\
$>10,000$ & 46774 & 45587 & 33803 & 43298 & 42117 & 31484 \\
$\begin{array}{c}\text { Total } \\
\text { Standard. Err. }\end{array}$ & 4568 & 4629 & 2669 & 4222 & 4273 & 2478 \\
\hline
\end{tabular}

Notes:

1. "All usable obs" is the subsample containing all the observations with valid values for the variables used to compute the output series according to the new measure, i.e., without the 12-quarter minimum requirement on the length of each BHC's time series.

2. "Final sample" contains all the observations of those BHCs that have at least 12 quarters of data, and it will be used in Wang (2003b) to estimate the production and the cost functions. 


\section{Appendix A. Additional Issues in the Imputation of a Bank's Service Output}

\section{Real materials input}

The model in Wang (2003a) does not explicitly consider purchased real materials (e.g., paper, stationery, telephone services, and utilities) used in the process of supplying services, and their value is still included in the output (to be called service gross output and denoted by $\mathrm{Y}^{\mathrm{S}}$ ) derived by subtracting the return to loanable funds from total interest income. The pure bank value added should be net of such materials, and how they are accounted for determines the specification of the cost function. That is, if the production function of $\mathrm{Y}^{\mathrm{S}}$ can be written as

$$
\mathrm{Y}^{\mathrm{S}}=\mathrm{G}^{\mathrm{S}}(\mathrm{K}, \mathrm{L}, \mathrm{M}) \text {, }
$$

where $\mathrm{M}$ is the materials input, then its dual service-gross-output cost function is

$$
\mathrm{C}^{\mathrm{Y}^{\mathrm{S}}}=\mathrm{C}^{\mathrm{Y}^{\mathrm{S}}}\left(\mathrm{Y}^{\mathrm{S}}, w, r^{K}, \mathrm{P}^{\mathrm{M}}\right),
$$

where $\mathrm{P}^{\mathrm{M}}$ is the price of $\mathrm{M}$, and $w$ and $r^{K}$ are the wage rate and capital rental price, respectively. Since $\mathrm{Y}^{\mathrm{S}}$ includes the real value of $\mathrm{M}, \mathrm{C}^{\mathrm{Y}^{\mathrm{S}}}$ contains the expenses on $\mathrm{M}$. If we assume that materials and the pure bank value added (denoted by $\mathrm{V}$ ) are separable in the production of $\mathrm{Y}^{\mathrm{S}}$ (i.e., $\mathrm{Y}^{\mathrm{S}}$ can be written as $\mathrm{Y}^{\mathrm{S}}=\mathrm{F}^{\mathrm{S}}(\mathrm{V}, \mathrm{M})=\mathrm{F}^{\mathrm{S}}\left(\mathrm{F}^{\mathrm{V}}(\mathrm{K}, \mathrm{L}), \mathrm{M}\right)$, where $\mathrm{V}=\mathrm{F}^{\mathrm{V}}(\mathrm{K}, \mathrm{L})$ is the value-added production function), then the cost function dual to $\mathrm{F}^{\mathrm{V}}\left(\right.$.) is $\mathrm{C}^{\mathrm{V}}=\mathrm{C}^{\mathrm{V}}\left(\mathrm{V}, w, r^{K}\right)$. The data confirm that the nominal value of $\mathrm{V}$ is about $94 \%$ of nominal $\mathrm{Y}^{\mathrm{S}}{ }^{22}$ This paper is the first to clarify the distinction between $\mathrm{Y}^{\mathrm{S}}$ and $\mathrm{V}$, as well as the corresponding distinction between $\mathrm{C}^{\mathrm{Y}^{\mathrm{S}}}$ (.) and $\mathrm{C}^{\mathrm{V}}($.$) .$

Without a priori evidence to assume separability between $\mathrm{M}$ and $\mathrm{V}$ in the generation of $\mathrm{Y}^{\mathrm{S}}$, $\mathrm{G}^{\mathrm{S}}($.$) is preferred to \mathrm{F}^{\mathrm{V}}($.$) , and \mathrm{C}^{\mathrm{Y}^{\mathrm{S}}}\left(\right.$ (.) to $\mathrm{C}^{\mathrm{V}}($.$) , as \mathrm{G}^{\mathrm{S}}($.) provides a more precise and complete description of the production technology. However, with only noisy data on the nominal value of $\mathrm{M}$ available, I choose to report $\mathrm{Y}^{\mathrm{S}}$ in this paper, and estimate a "hybrid" cost function: $\mathrm{C}^{\mathrm{V}}\left(\mathrm{Y}^{\mathrm{S}}, w, \mathrm{r}_{\mathrm{K}}\right)$. This is because the approximated $\mathrm{V}$ is so noisy that it severely biases down the coefficient on output and thus yields unreasonably high estimates of $\gamma^{\mathrm{C}}(\approx 9){ }^{23}$

\section{Data problems related to price indices}

In addition to the measurement errors in nominal $\mathbf{Y}^{\mathrm{A}}$, real $\mathbf{Y}^{\mathrm{A}}$ is also subject to the error introduced by using a single industry price index $\left(\mathbf{P}^{\mathrm{A}}\right)$, instead of bank-specific $\mathbf{P}_{\mathrm{i}}^{\mathrm{A}} . \mathbf{P}^{\mathrm{A}}$ is the valid

\footnotetext{
${ }^{22} \mathrm{~V}=\mathrm{R}^{\mathrm{S}}-\mathrm{C}^{\mathrm{M}}$, where $\mathrm{v}, \mathrm{R}^{\mathrm{S}}$ and $\mathrm{C}^{\mathrm{M}}$ are the nominal values of $\mathrm{V}, \mathrm{Y}^{\mathrm{S}}$ and $\mathrm{M}$, respectively. In the data, the closest match to $\mathrm{C}^{\mathrm{M}}$ is a variable labeled "non-interest expenses" (other than salaries and capital depreciation), but it also contains net gains from sales of assets that are not trading securities, as well as miscellaneous overhead that is essentially labor and capital costs (e.g., $R \& D$ costs). $\mathrm{R}^{\mathrm{S}}$ is approximated by the imputed service revenue.

${ }^{23} \mathrm{~V}$ is approximated by $\left(\mathrm{R}^{\mathrm{S}^{\prime}}-\mathrm{C}^{\mathrm{M}}\right) / \mathrm{P}$, where $\mathrm{R}^{\mathrm{S}^{\prime}}$ is the service revenue and $\mathrm{C}^{\mathrm{M}}$ is the "non-interest expenses," while $\mathrm{P}$ is that price index compiled by BEA. Ideally, $\mathrm{V}$ should be computed either as a Divisia index or by
} 
deflator if there is perfect competition in the market for bank services; otherwise a bias of $\left(\mathbf{P}_{i}^{\mathrm{A}} / \mathbf{P}^{\mathrm{A}}\right)$ results in the measured $\mathbf{Y}^{\mathrm{A}}$. Since imperfect competition is likely given the lack of information about A's products, this subjects the production function estimation to the bias documented by Klette and Griliches (1996). In fact, outputs will be overstated for banks that charge higher prices and raise prices faster than the rest of the industry.

Another issue, relevant for a cross-section comparison or aggregation of A's output, is crossbank quality differentials in their information services. Ideally, $\mathbf{Y}^{\mathrm{A}}$ of each bank should be measured in quality-adjusted units, rather than simply in the number of each category of loans processed, since loans within the same observed category are likely to have different characteristics (e.g., expected default risk, industry, loan size, and customer relationship) across banks that affect the amount of processing needed. ${ }^{24}$ One way to adjust for quality is to convert every bank's output into units of the numeraire good using the cross-bank relative price in the base period as the quality weight. ${ }^{25}$

The same quality adjustment also applies to aggregating the value added of Divisions A and $\mathrm{C}$ into a bank's total value added for purposes of estimating the production function when only the total quantity of each primary input is observed. In general, aggregate value added of a bank producing $J$ products is:

$$
Y_{t}^{*}=\sum_{j=1}^{J}\left(\operatorname{Re} v_{t}^{j} / P_{t}^{j}\right)\left(P_{0}^{j} / P_{0}^{1}\right)
$$

where $\operatorname{Re} v_{t}^{j}$ is the revenue (net of materials) and $P_{t}^{j}$ the price index of product $j$ in period $t$, while $\left(P_{0}^{j} / P_{0}^{1}\right)$ is $j$ 's base-period relative price. Without base-period relative prices $\left(P_{0}^{j} / P_{0}^{1}, j=\mathrm{A}, \mathrm{C}\right), \mathrm{I}$ calculate the aggregate value added of each bank as $Y_{t}=\operatorname{Rev}_{t}^{A} / P_{t}^{A}+\operatorname{Rev}_{t}^{C} / P_{t}^{C}$.

One last source of measurement errors in imputed $\boldsymbol{Y}_{t}^{A}$ is varying - not constant as assumedloan balances and interest rates within a period. Only the period-end loan balance $\left(B_{\tau}\right)$ and average interest rate $\bar{r}=\left(\sum_{s=1}^{\tau} r_{s}\right) / \tau$ are available, where $\tau$ is the number of days during each period. It is clear

double deflating $\mathrm{Y}^{\mathrm{S}}$ and $\mathrm{M}$, i.e., $\mathrm{V}=\mathrm{Y}^{\mathrm{S}}-\mathrm{M}=\mathrm{R}^{\mathrm{S}} / \mathrm{P}^{\mathrm{S}}-\mathrm{C}^{\mathrm{M}} / \mathrm{P}^{\mathrm{M}}$, where $\mathrm{P}^{\mathrm{S}}$ is the price index for $\mathrm{Y}^{\mathrm{S}}$.

${ }^{24}$ For instance, loans of higher denominations are likely to require more effort in credit screening, so are loans subject to higher default probabilities, but the input requirement is likely to be non-linear in the characteristics. In fact, $\mathbf{Y}^{\mathrm{A}}$ is best measured in terms of characteristics, and the production function defined in the characteristic space. So, one approach is to estimate a hedonic cost function. For a general exposition of the adjustment of output quality, see Triplett (1983). The same issues exist for every category of loans within a bank.

${ }^{25}$ Illustrated in a single-output case, the quality-adjusted output of bank $i$, i.e., its output in units of the numeraire product, is calculated as $Y_{i t}{ }^{*}=\left(\operatorname{Rev}_{i t} / P_{i t}\right)\left(P_{i 0} / P_{10}\right)$, where $P_{i t}$ is the price index for bank $i$ at time $t$, and $\operatorname{Rev} v_{i t}$ its revenue. $P_{10}$ is the base-period price of the numeraire good, and $\left(P_{i 0} / P_{10}\right)$ is the relative price of bank $i$ 's product. This calculation follows the same logic as that used in the aggregation of different products of an economy. When only the industry deflator $\left(P_{t}\right)$ is available, it biases the true real output by $\left(P_{i t} / P_{t}\right)\left(P_{10} / P_{i 0}\right)$, since $Y_{i t}=\operatorname{Rev}_{i t} / P_{t}=Y_{i t}^{*}\left[\left(P_{i t} / P_{t}\right)\left(P_{10} / P_{i 0}\right)\right]$. In reality, no base-period relative prices are available. 
that $\bar{r} B_{\tau}$ is not the correct loan interest returns. The same problem affects the imputation of C's output using the balance of deposits.

\section{Appendix B. Additional Statistics for the Data and the Sample}

I check the relation between quarterly average values of the balance sheet items and their endof-quarter counterparts, as well as the mean of beginning-of-quarter and end-of-quarter values, for those variables with quarterly average figures available. The results indicate that, on average, the differences are trivial for variables such as total assets, earning assets (defined as the sum of securities and loans) and equity, although there are noticeable cross-section variations. Neither do most of the major asset ratios based on end-of-quarter and quarterly average figures differ significantly. The exceptions are security holdings and net loan balances. So it seems that using the end-of-quarter figures of the relevant balance sheet items, necessary given the available data, may generate results not much inferior to those from using the (preferred) quarterly average values.

Table B.1 reports summary statistics for some important ratios. Sample means are computed by averaging the time-series mean ratios of each BHC. These ratio statistics thus reflect the balance-sheet composition of an average bank. I also calculate the sample mean ratios using the sample mean levels for the denominators and numerators, which reflect the average composition of a currency unit, mainly to check if there are any major biases in bank asset or income composition across different size groups. (Small banks have more weight in the first type of means, whereas large banks have more weight in the second type.) I compare the sample average of the same set of balance sheet variables by quarter. There appears to be little seasonality in either the level or the composition of these variables.

In contrast, more patterns can be detected in Figure 7, which reports the yearly pattern of the same set of ratios. The fraction of (net) loans in total financial assets remains relatively stable over the same period, trending slightly upward in the last five years. Of all the loan categories, RE, C\&I, and consumer loans are the three most important ones. Among them, the most obvious pattern is the steady rise in the relative volume of RE loans within the total loan portfolio throughout the 1990s. One possible reason is that the capital adequacy requirement assigns a lower risk weight to residential mortgages, and banks respond by holding more RE loans on their books. Other explanations build upon arguments of comparative advantage and market power. That is, banks have realized that they have a cost advantage in originating mortgages in the deregulated environment, and they probably also possess relatively more market power in this activity. Yet another reason may be the decline of savings and loans (S\&Ls), which used to issue and hold the majority of residential mortgages before the S\&L crisis in the early 1990 s. 
Another pattern is the gradual fall in the portion of C\&I loans in banks' loan portfolios. They seem to have been "crowded out" by RE loans. At the same time, the relative amount of consumer loans (which include credit card plans) has also dropped slightly over time, coupled with an increase in the variance. One possible explanation is that finance companies (such as GMAC) play a bigger role in supplying credit to consumers, while an increasing fraction of bank lending to consumers (especially credit card plans) is concentrated in a handful of large banks these days.

The remaining two loan categories (lease financing and agricultural loans) are fairly minor, and their relative magnitudes stable. A few more words are needed for the somewhat special situation of agricultural loans. These loans include only the credit extended as "working capital" for agricultural production, but not those loans made to fund capital investment and real estate, which are included in C\&I loans and RE loans, respectively. Also, agricultural loans are quite concentrated in certain banks, many of which are small and not affiliated with a BHC. The other banks, in contrast, have very low percentages of agricultural loans, and this seems to be the case for most BHCs in this sample. One last asset item is the federal funds sold (and securities bought with agreements to resell); this item remains minor, slightly more so in the 1990s.

Figures B.1 and B.2 depict the composition of asset and loan portfolios across different size groups. Relative to small BHCs, large BHCs tend to hold a higher ratio of loans to securities in their asset portfolios, and a higher proportion of C\&I loans, consumer loans, and lease financing receivables, but a lower proportion of RE loans and agricultural loans in their loan portfolios. These features most likely reflect the need of small BHCs to hold relatively more liquid assets (e.g., market securities) in order to manage liquidity risk. 
Table B.1 Composition of Major Balance-Sheet Items, and Important Income and Expense Ratios

Balance Sheet Items

\begin{tabular}{lc}
\hline Cash Equivalents & 6.02 \\
Total Loans (Net of Allowances) & 58.81 \\
C\&I Loans & 12.59 \\
RE Loans & 32.81 \\
Agricultural Loans & 2.57 \\
Loans to Individuals & 9.70 \\
Lease Financings & 0.56 \\
Fed Funds Sold \& Repo Agreements & 3.46 \\
Fixed Assets & 1.91 \\
Total Liabilities & 92.43 \\
Equity & 8.08 \\
Loan Loss Allowances & 0.98 \\
\hline
\end{tabular}

$\%$ of Total Assets

-

Balance Sheet Items

\begin{tabular}{lc}
\hline Deposits & 90.52 \\
Fed Funds Bought & 3.38 \\
Subordinated Debt & 0.28 \\
Other Borrowings & 3.81 \\
\hline
\end{tabular}

$\%$ of Total Liabilities

90.52

0.28

\section{Major Ratios and Interest Rates}

Gross Rate of Interest Income (Receipts)

Explicit Fee Income/Total Interest Income

Explicit Fee Income/Non-Interest Expenses

Avg. Rate of Interest Payments

Deposit Interest Rate

Non-Interest/Interest Expenses 


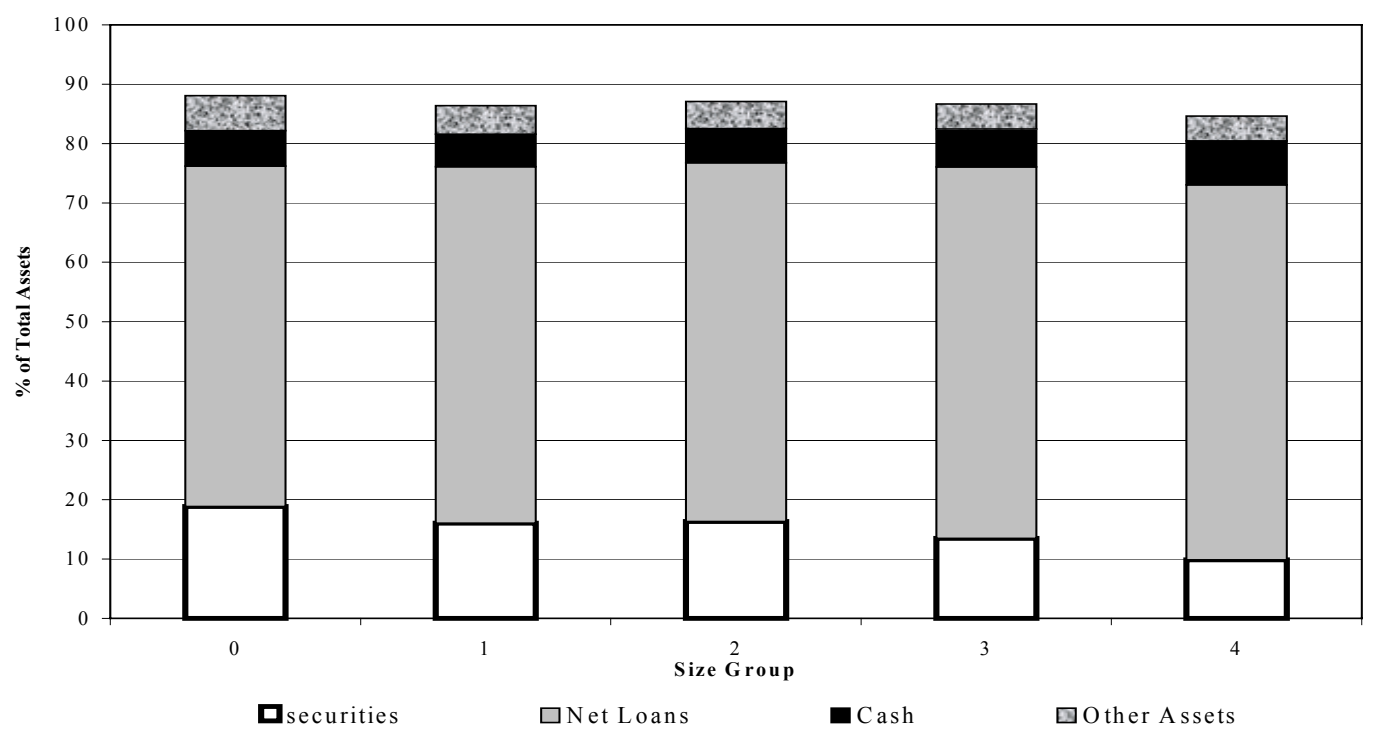

Notes: Size group 0: total assets $<\$ 500$ mil.

1 : total assets $(\$ 500 \mathrm{mil}-\$ 1,000 \mathrm{mil})$

2: total assets $(\$ 1,000-\$ 5,000)$

4: total assets $>\$ 10,000$

3: total assets $(\$ 5,000-\$ 10,000)$

Figure B.1 Main Categories of Bank Assets, Composition by Size Group

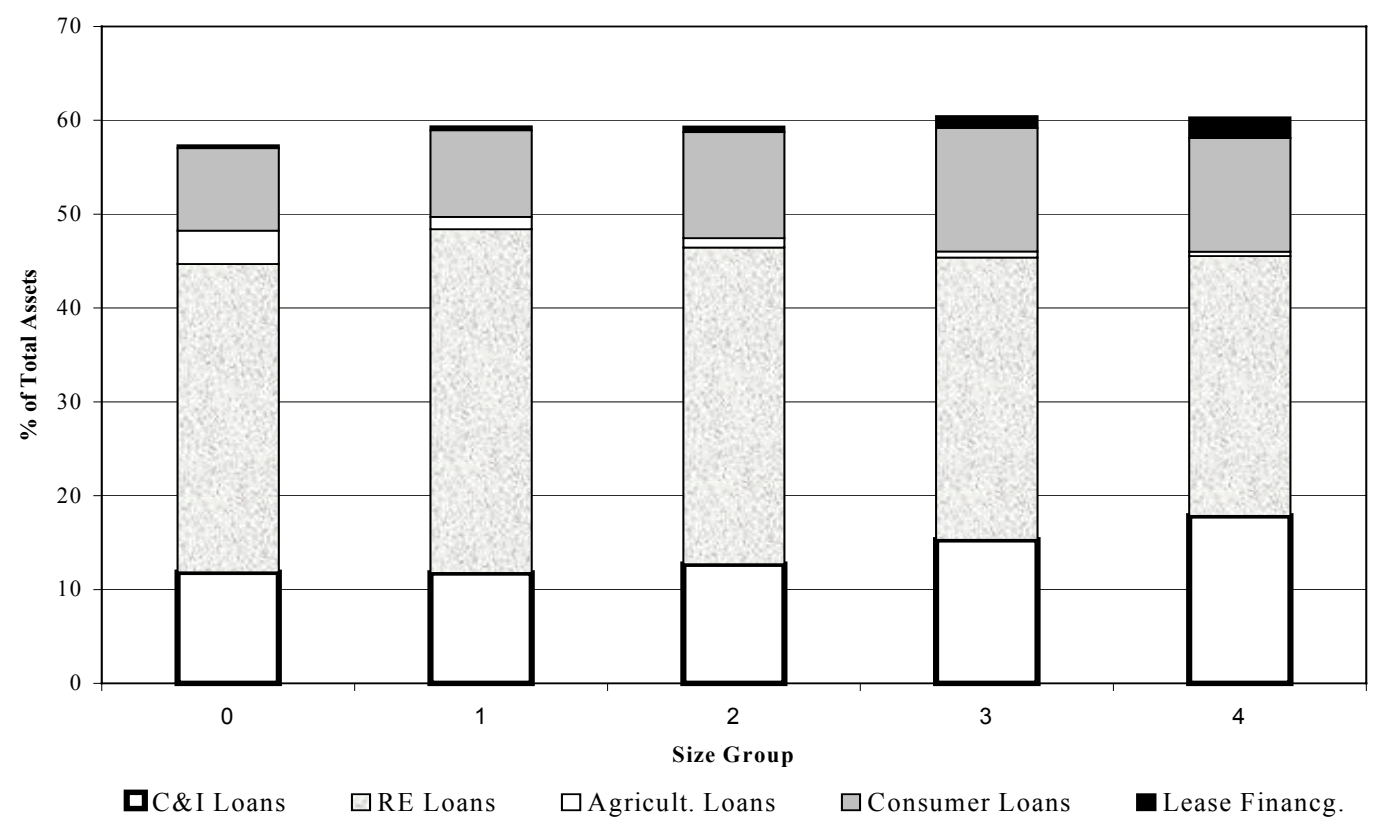

Figure B.2 Composition of Bank Loans across Size Groups 


\section{Appendix C. Data Items Used to Construct the Outputs of the Three Banking Functions}

\begin{tabular}{|c|c|c|c|}
\hline \multirow[t]{2}{*}{ Division } & \multicolumn{2}{|l|}{ Output (Y) } & \multirow[t]{2}{*}{ Inputs } \\
\hline & $\begin{array}{c}\text { Nominal Value } \\
\end{array}$ & Price Index & \\
\hline $\begin{array}{l}\text { A } \\
\text { (Loan } \\
\text { origination } \\
\text { and } \\
\text { monitoring) }\end{array}$ & $\begin{array}{l}\text { 1. } \\
\text { Explicit revenue: } 4070+4399,{ }^{26} \\
\text { Implicit revenue: } \\
\text { (loan interest + lease financing income) - } \\
1410^{*} \text { opportunity cost for mortgage lending } \\
-1590^{*} \text { farm loan rate }-1766^{*} \text { opportunity } \\
\text { cost for C\&I loans - LOANIND*car loan } \\
\text { rate }-2165^{*} \text { lease financing rate }-1563^{*} \mathrm{FF} \text {. }\end{array}$ & GDP deflator & $\begin{array}{l}\text { L (labor) } \\
\text { K (physical } \\
\text { capital) }\end{array}$ \\
\hline $\begin{array}{c}\text { B } \\
\text { (Financing) }\end{array}$ & $\begin{array}{l}\text { The quarterly balance of } \\
\text { 1. Market securities }(0390) \text {, } \\
\text { 2. Various categories of loans: } \\
\text { (1766+1590+2165+1563), (1410), } \\
\text { LOANIND, and FFSOLD. }\end{array}$ & GDP deflator & $\begin{array}{l}\text { Loanable } \\
\text { funds: } \\
\text { D (deposits) } \\
+ \\
\text { E (equity) }\end{array}$ \\
\hline $\begin{array}{c}\text { C } \\
\text { (Depositor } \\
\text { services) }\end{array}$ & $\begin{array}{l}\text { 1. Explicit revenue: } 4483 \text {, } \\
\text { 2. Implicit revenue: } \\
\mathrm{r}^{\mathrm{F} *[(6631+6636)-2604]-4176}\end{array}$ & $\begin{array}{l}\text { index for } \\
\text { (implicitly } \\
\text { priced) } \\
\text { depositor } \\
\text { services }\end{array}$ & $\begin{array}{l}\mathrm{L} \text { (labor) } \\
\mathrm{K} \text { (physical } \\
\text { capital) } \\
\mathrm{k}^{*} \mathrm{D} \text { (cash } \\
\text { reserves) }\end{array}$ \\
\hline
\end{tabular}

Notes:

1. Data items

4070: income from fiduciary services

4078: other non-interest income, such as income received for performing data processing services for others, but also includes net gains (losses) from the sale of assets (such bank premises) other than securities and trading assets

4399: services charges, commissions and fees for other services such as rental of safe deposit box

Loan interest income-LOANINT: interest, and fees on loans in domestic (4393) and foreign (4059) offices, excluding obligations (other than securities) of states and political subdivisions

Lease financing income-LEASINC: Income from lease financing receivables $(4065,4505$ and 4307)

0390: book value of all investment securities (held-to-maturity and available-for-sale)

Various categories of loans:

1410: balance sheet value of real estate loans

1590: loans to finance agricultural production, and other loans to farmers

1766: commercial and industrial loans

LOANIND: Loans to individuals for household, family, and other personal expenditures

2165: lease financing receivable (net of unearned income)

1563: other loans, mostly for purchasing or carrying securities

\footnotetext{
${ }^{26}$ I exclude one category of the reported non-interest incomes (4078) from the explicit bank output, because it contains mostly net gains from sales of assets other than trading securities. This may understate the output of some BHCs, perhaps especially the large ones, as this category does contain a few items of true services, such as data processing services. Excluding 4078 introduces more measurement errors and thus further biases up the estimates of returns to scale. The additional distortion is unlikely to be serious, since many BHCs report zero value for such incomes.
} 
FFSOLD: Fed funds sold and securities purchased for resale

4483: total amount of service charges on depositor accounts in domestic offices

6631: the amount of all non-interest-bearing deposits in domestic and foreign offices

6636: the amount of all interest-bearing deposits in domestic and foreign offices

2604: all outstanding time deposits of $\$ 100,000$ or more, both negotiable and nonnegotiable

4176: interest expense on all deposits except for 2604.

2. Regarding the loan balances-B's output:

For the sample as a whole, the sum of the reported categories of loans (listed above) adds up to $98.7 \%$ of the gross loan balance (data item 2122), with a standard deviation of $4 \%$. For those BHCs whose sums fall short of the gross balance, I append the gap to 1563.

3. The proxies for proper expected rates of return

$\mathrm{r}^{\mathrm{F}}$ : 90-day Treasury bill rate

Mortgage rate: FHA 30-year mortgage rate

C\&I loan rate: 90 -day commercial paper $(\mathrm{CP})$ rate (or prime loan rate)

Farm loan rate: approximated using $\mathrm{CP}$ rate

Car loan rate: use Lehman Brother's index on asset-back bonds as a proxy for the expected rate of return on consumer loans

Lease financing rate: approximated using $\mathrm{CP}$ rate

FF: Federal funds rate, very close to the over-night repo rate, to approximate the expected rate of return on lendings (1563) for dealing in securities. 


\section{Bibliography}

Akerlof, G. (1970). "The Market for 'Lemons': Quality Uncertainty and the Market Mechanism," Quarterly Journal of Economics 84(3), p. 488-500.

Berger, A. N. and D. B. Humphrey (1997). "Efficiency of Financial Institutions: International Survey and Directions for Future Research," European Journal of Operational Research 98(2), p. 175-212.

Bernanke, B. S. and A. S. Blinder (1992). "The Federal Funds Rate and the Channels of Monetary Transmission," American Economic Review 82(4), p. 901-21.

English, W. B. and W. R. Nelson (1998). "Profits and Balance Sheet Developments at U.S. Commercial Banks in 1997," Federal Reserve Bulletin, p. 391-419.

Hancock, D. (1985). "The Financial Firm: Production with Monetary and Nonmonetary Goods," Journal of Political Economy 93(5), p. 859-80.

Moulton, B. R and E. P. Seskin (2003). "Preview of the 2003 Comprehensive Revision of the National Income and Product Accounts, Changes in Definitions and Classifications," Survey of Current Business, June, p. 17-34.

Rogers, K. E. (1998). "Nontraditional Activities and the Efficiency of US Commercial Banks," Journal of Banking and Finance 22(4), p. 467-82.

Ross, S. A. (1976). "The Arbitrage Theory of Capital Asset Pricing," Journal of Economic Theory 13(3), p. 341-360.

Stiroh, K. (1999). "How Did Bank Holding Companies Prosper in the 1990s?” Journal of Banking and Finance, forthcoming.

Triplett, J. E. (1983). "Concepts of Quality in Input and Output Price Measures: A Resolution of the User-Value Resource-Cost Debate," in M. F. Foss (ed.) The U.S. National Income and Product Account: Selected Topics, University of Chicago Press, Chicago.

Wang, J. C. (2003a). "Loanable Funds, Risk, and Bank Service Output," Federal Reserve Bank of Boston, Working Paper 03-4, July 2003.

Wang, J. C. (2003b). "Productivity and Economies of Scale in the Production of Bank Service Output," Federal Reserve Bank of Boston, Working Paper 03-7, forthcoming. 